\title{
Çalışanların Örgütsel Adalet Algısı ve Tükenmişlik Düzeylerinin Çalışan Sessizliği Üzerindeki Etkisi ${ }^{1}$
}

\author{
Kemal Eroğluer ${ }^{\mathrm{a}}$
}

\author{
Recep Caner Erselcan ${ }^{\mathrm{b}}$
}

\begin{abstract}
Öz: Toplumsal yaşamın önemli aktörlerinden olan örgütlerde çalışanlar, örgütsel başarının temel unsurudur. Örgütün başarısı uyguladığı yönetim tekniklerine sıkı sıkıya bağlıdır. Çalışanların örgütsel işleyiş ve süreçler ile ilgili adalet algıları, örgütlerine olan desteklerini ve süreçlere katılımlarını etkiler. Çalışanların örgütsel adalet algısı tükenmişlik düzeyleri üzerinde etkili olabilir. Düşük adalet algısının, tükenmişlik düzeyinin artmasına ve çalışanların süreçlere olan desteğinin ve katılımının azalması ve zamanla ortadan kalkması ile çalışanlarının sessiz kalmasına neden olabileceği ifade edilebilir. Bu çalışma izmir, Bursa ve Balıkesirde aynı sektörde faaliyet gösteren üç imalat firmasının 209 çalışanı üzerinde yapılmıştır. Elde edilen verilerin analizinde tanımlayıcı istatistikler, korelasyon, regresyon analizleri kullanılmıştır. Bu çalışmada örgütsel adalet alt boyutlarının tükenmişlik alt boyutlarından duygusal tükenme, duyarsızlaşma ve kişisel başarıda azalma hissini olumsuz yönde etkilediği, örgütsel adalet alt boyutlarının çalışan sessizliğini olumsuz yönde, tükenmişlik alt boyutlarından duyarsızlaşma ve kişisel başarıda azalma hissinin çalışan sessizliğini olumlu yönde etkilediği sonucuna ulaşılmıştır. Literatür incelendiğinde bu üç konuyu birlikte ele alan çalışma sayısının oldukça kısıtı olduğu, bu anlamda katkı sağlayacağı düşünülmektedir.
\end{abstract}

Anahtar Sözcükler: Örgütsel Adalet, Tükenmişlik, Çalışan Sessizliği, İmalat Sektörü

JEL Sınıflandırması: M10, M12, J53

\section{The Impact of The Employees' Organizational Justice and Burnout Levels on Perceptions of Organizational Silence}

\begin{abstract}
Employees in organizations that are important actors of social life are the basic element of organizational success. Accomplishment of an organization is closely tied to the management applications to be followed. Perception of employees on justice of organizational operations and procedures affect their support and participation in the processes Employee' perception of organizational justice may have impact on burnout levels. It can be argued that low employee perception of justice can lead to increase in the level of burnout and decrease of their support and attandance tol procedures and diminishs with the time being finally causes employee silence. This study has been made on 209 employees of three manufacturing company which are operating in izmir, Bursa and Balıkesir. Obtained data has been evaluated by the corelation, regression analyzes and decriptive stastistics. In this study following results have been reached; sub-dimensions of organizational justice affected emotional burnout, depersonalization and decline in personal sense of achievement negatively and sub-dimensions of organizational justice affect the employee silence negatively, although depersonalization and sense of decline in personal achievement affect employee silence positively. It is thought that the number of studies that deal with these three subjects is very limited and it will contribute in this sense.
\end{abstract}

Keywords: Organizational Justice, Burnout, Employee Silence,Manufacturing Sector

JEL Classification: M10, M12, J53

aPhD., Turkish Land Forces, Maintenance School and Training Center, Balıkersir, Turkiye, k_erogluer@yahoo.com.tr

bPhD. Student, Dokuz Eylul University, Institute of Social Sciences, Izmir, Turkiye, cerselcan@hotmail.com 


\section{Giriş}

İçinde bulunduğumuz dönemde yıkıcı rekabet örgütlerin temel problemleri arasında ilk sırada yer almaktadır. Bu rekabet ortamı örgütler ve çalışanlar üzerinde baskı unsuru oluşturmaktadır. Örgütün başarısı kaliteli çalışanlara sahip olması kadar, çalışanların örgütü, yaptıkları işi benimsemeleri ve bu duyguyla çalışmalarının sağlanmasına bağlıdır. Bunun yanında çalışanlara yönelik olarak örgütün izlediği politikalar örgütsel başarı için anahtar rol oynamaktadır. İşyerinde birbiriyle ilişkili olan iki önemli konu vardır. Bunlar adalet ve sessizliktir. Biri artarken diğerinin azalması beklenir (Torun, 2015). Çalışanların iş ortamındaki davranışları üzerinde örgütteki adalet algısının çok önemli bir yeri vardır. Adil olmayan veya o şekilde algılanan davranış ve uygulamalar çalışanların zamanla tükenmişlik duygusuna kapılmalarına, tepkisiz kalmalarına ve sonunda kendi içine kapanmalarına, sessizleşmelerine neden olabilir. Örgütün süreçlerinde ve uygulamalarında adaletsizlik algısına sahip olan çalışanlar beklentileri karşılıksız kalınca tükenmişlik hissine kapılabilecek, örgütlerine olan katkıları zamanla azalabilecek, fikir ve düşüncelerini paylaşmayarak sessiz kalabileceklerdir.

Bu bağlamda başarıyı arttrabilmek için örgütlerin entellektüel sermayesi olan çalışanların üzerinde adalet algısının etkisi, tükenmişlik düzeyinin çalışanlar üzerindeki etkileri, örgütlerde ortaya atılan bir düşünce bile çok önemli gelişmelere neden olabilirken, çalışanların düşünce ve fikirlerini paylaşabilmeleri ya da süreçlere katılım sağlamadan sadece kendilerine verilen işi yaparak sessiz kalmaları gibi konuları açıklayabilmek için ulusal ve uluslararası literatürde üç konuyu birlikte inceleyen çalışmalar araştrılımıştr. Ulusal literatürde benzer bir çalışmaya ulaşılamamış, uluslararası literatürde ise Tahmasebi (2013) ile Whiteside ve Barclay (2013)'ın benzer çalışmalarına ulaşılmıştır. Dolayısıyla çalışmanın literatüre ve uygulamaya yönelik önemli katkı sağlayabileceği değerlendirilmektedir.

İmalat sektörü özelliği itibariyle çalışanların üretimde bizzat rol oynadıkları, üretim sürecinin içinde yer aldıkları bir sektördür. Bu nedenle örgütsel ilişkilerde daha katılımcı olabilecekleri, örgüt politikalarından etkilenip, süreçleri etkileyebilecekleri değerlendirilmektedir. Bu noktadan hareketle imalat sektöründe örgütsel adalet algısı ve tükenmişlik düzeyleri arasında olumsuz yönlü iliş̧i (Yeniçeri, Demirel ve Seçkin; 2009: 83) ve çalışan sesizliğinin düşük seviyede olması (Bildik, 2009) beklendiğinden bu sektörde çalışma yapılmıştr. Bu çalışmada örgütsel adalet algısı ve tükenmişlik düzeylerinin çalışanların sessizliği üzerindeki etkilerinin incelenmesi amaçlanmıştır. Çalışanların olumlu yöndeki örgütsel adalet algılarının tükenmişlik düzeyi ve çalışan sessizliğini azaltarak örgütsel işleyişe destek olabileceği değerlendirilmektedir. Bu maksatla oluşturulan hipotezlerin doğrulanması için örgütsel adalet alt boyutlarının herbirinin tükenmişlik alt boyutlarının herbiri ile ilişkileri, örgütsel adalet alt boyutlarının çalışan sessizliği ve tükenmişlik alt boyutlarının yine çalışan sessizliği ile ilişkileri incelenmiştir.

\section{2. Örgütsel Adalet}

Insanların her türlü faaliyetlerinde, toplu yaşamın düzenlenmesinde ve örgütlerin işleyişinde adalet algısı çok önemlidir. Insanların diğer insanlarla, örgütlerle ve kurumlarla olan ilişkilerinde bekledikleri değerlerin başında gelen kavramlardan biri adalettir. Arapça kökenli olan adalet kavramı "iyilik, doğruluk, yerine getirme, hak, hukuk ve eşitlik gibi değer yargılarını içermekte ve uyumluluk, düzgünlük ve bir düzenin doğruluğu anlamına gelmektedir" (Çakır, 2006: 30). "Adalet" kavramının sözlük anlamı "hak ve hukuka uygunluk, hakkı gözetme, doğruluk, herkese kendine düşeni verme, kendi hakkı olanı verme" olarak belirtilmiştir (TDK, 2005: 18).

Adams'ın (1965: 280) "Adalet Teorisi" örgütsel adalet konusunun temel çalışmalarından birisidir. Adams, örgütsel adalet konusunu bir çalışanın örgütüne olan katkısı sonucu elde ettiği kazanımı başka bir örgütteki çalışanın elde ettiği kazanımı ile karşılaştırması şeklinde ifade etmiştir (Yeniçeri vd., 2009: 84).

Adalet kavramı zamanla sadece sosyal açıdan değil yönetimsel ve örgütsel açıdan da incelenmiştir. Demirel ve Dinçer (2011: 30) adaleti "bir sistemin dayandığı, temel ilke, değer ve inançların o sistem içerisinde yer alan bireylere negatif ayrımcılık yapmadan uygulanması" şeklinde tanımlamışlardır. Adaleti her birey farklı algılayabilir. Etik ve ahlaki değerler davranışların ölçüsü olarak kabul edilebilir. İçerli (2010: 69) adalet kavramının bir davranış veya tutumun belirlenen ilkelere uygun olup olmamasını ifade ederken kullanıldığını; 
örgütlerde ise yöneticilerin davranışlarının adil olup olmadığını belirtmek için "örgütsel adalet" kavramının kullanıldığını ifade etmiştir (Çetinkaya ve Çimenci, 2014: 242).

Özer ve Urtekin (2007: 109) örgütsel adaleti “örgütsel kazanımların dağıtılması, dağıtım kararlarının alınmasında yapılan işlemler, kullanılan yöntemler ve kişiler arasındaki etkileşimin gerektirdikleri ile ilgili geliştirilen kurallar ve sosyal normlarla ifade edildiğini" belirtmişlerdir.

Örgütsel adalet, iş yerinde elde edilen sonuçlar ve uygulanan süreçler dikkate alındığında çalışanlara ne kadar adil davranıldığı duygusunun ölçüsü olarak ifade edilebilir (Eigen ve Litwin, 2014: 172). Örgütsel adalet kapsamında, kaynakların dağıtımı, karar verme sürecindeki adalet ve kişiler arası davranışlar gibi iş yerindeki adalet, örgütsel adalet olarak tanımlanmıştır. Bu bağlamda örgütsel adalet çalışanların iş yerlerindeki uygulamalara karşı zihinlerinde geliştirdikleri adalet algısıdır (Greenberg, 1990). Örgütlerde her çalışana adil davranmak, eşit firsatlar sağlamak, adil maaş, bilgiye ve kaynaklara adil ve eşit ulaşma imkanı gibi konular önem kazanmıştır. Bu konular ise örgütsel adaletin tanımı içinde yer almıştır (Banerjee ve Banerjee, 2013: 36).

Örgütsel adalet; "yöneticilerin örgüt ve çalışanlarla ilgili karar ve uygulamalarının, çalışanlar tarafindan olumlu şekilde algılanması olarak tanımlanırken, örgüt içerisinde ücretlerin, ödüllerin, cezaların ve terfilerin nasıl yapılacağı, bu tür kararların nasıl alındığı ya da alınan bu kararların çalışanlara nasıl söylendiğinin, çalışanlarca algılanma biçimi" şeklinde belirtilebilir (İçerli, 2010: 69).

Dağıtımsal, işlemsel ve etkileşimsel adalet örgütsel adaletin alt boyutları olarak sayılabilir. Dağıtımsal adalet, çalışanların daha önce belirlenen davranışları sergilemeleri durumunda belirlenen kazanımlara ulaşmalarını sağlar. İşlemsel adalet çalışanlar için elde edebilecekleri kazanımların nasıl belirleneceği veya ödüllendirme işlemlerine ne şekilde katkı sağlayacaklarını ifade eder (İşcan ve Naktiyok, 2004: 183).

\subsection{Dağıtımsal Adalet}

Örgütlerde çalışanların işe olan katkıları ve bu katkıların sonucu olarak elde ettikleri kazanımları, diğer çalışanların katkıları ve elde ettikleri kazanımları değerlendirmesinde algıladığı adalet olarak ifade edilmiştir (Meydan, Şeşen ve Basım; 2011: 46). Dağıtımsal adalet bilgi birikimlerini, tecrübelerini ve yeteneklerini örgüt için kullanması ve karşılığında yönetimin adil ücret, çalışma şartlarında iyileştirme, kazanımların dağııımında adil davranılması gibi hususları bu gayretlerle örtüştürmesi olarak belirtilmiştir (Yeniçeri vd., 2009: 85). Dağıtımsal adalet örgütün maaş, ödül, ceza ve yükselme gibi uygulamalarının çalışanlarca adil olduğuna inanılmasını ifade eder (İşcan ve Naktiyok, 2004: 183; Shibaoka, Takada, Watanabe, Kojima, Kakinuma, Tanaka ve Kawakami; 2010: 67). Dağıtımsal adalet genel olarak örgütsel kaynakların ve elde edilen ekonomik kazanımların paylaştııımasının adil olarak algısı üzerine yoğunlaştı̆̆ı ifade edilebilir (Altıntaş, 2006: 20).

\section{2. İşlemsel Adalet}

İ̧ yerinde işlemsel adalet çalışanların işe yönelik davranışları ve performansları için önemli bir güdüleyicidir (He, Zhu ve Zheng, 2014; 681). İşlemsel adalet, çalışanların karar süreçlerine katılmaları ve bu süreçlerin şeffaflığı ve tarafsızlığı ile ilgilidir. İşlemsel adalet yönetici ve uygulanan süreçlerle ilgilidir. Alınan kararları uygulayan yöneticilerin bu süreçte sergiledikleri tutum ve davranışlarında adil olmaları ile örgütün ilke ve politikalarının çalışanlarca adil olduğunun algılanmasının işlemsel adalet ile ilgili olduğu ifade edilmiştir (Yeniçeri vd., 2009: 86). Süreç adaleti olarak da adlandırılan işlemsel adalet, örgütün belirlediği süreçler sonunda alınan kararın yönetici tarafindan uygulanmasının çalışanlar tarafindan adil olarak algılandığı belirtilmiştir (Meydan vd., 2011: 47). İşlemsel adalete ilişkin çalışanları etkileyen iki önemli faktör olduğu ifade edilmiştir. Bunlardan biri karar vericinin karardan etkilenenlere karşı gösterdiği tavır ve davranışken, diğeri alınan karara ilişkin yeterli ve kabul edilebilir seviyede açıklama yapmasıdır. Bu iki faktörün işlemsel adalet algısı üzerinde olumlu etkisi olduğu ifade edilebilir. İşlemsel adalet, liderin performans değerlendirmesinde ve çalışanların lidere karşı olan güveninin belirlenmesinde önemli rol oynadığı ifade edilmiştir (Çetinkaya ve Çimenci, 2014: 249). 


\subsection{Etkileşimsel Adalet}

Yöneticilerin elde edilen kazanımların dağıtımına ilişkin kararlarının alınma şeklini çalışanlara karşı saygı sınırları içinde, doğru ve samimi bir şekilde açıklamaları olarak ifade edilebilir (İçerli, 2010: 86). Benzer şekilde etkileşimsel adaletin yöneticilerin çalışanlara karşı tavır ve davranışları ile örgütte alınan kararlar ve bu kararlara yönelik açıklamaların çalışanların adalet algısını etkilediği belirtilmiştir (Iş̧başı, 2001: 60). Örgütte alınan kararların çalışanlara iletilme, bildirilme şekli çalışanların etkileşimsel adalet algısını etkilemektedir. Çalışanlar söz konusu kararların kendilerine iletilmesinde yöneticilerin diğer çalışanlara davrandıkları gibi davranmalarını bekler. Etkileşimsel adalet algısının olumsuz olması çalışanların yöneticilerine karşı tepki geliştirmesine neden olabilir (Yeniçeri vd., 2009: 87).

\section{Tükenmişlik}

Günümüzde teknolojik gelişmelerin beraberinde getirdiği pek çok olumsuz duygusal durumdan birisi de tükenmişliktir. Bu kavram ilk kez 1970'li yılların ortalarında Alman psikolog Herbert Freudenberger tarafindan insanlarla ilişkileri fazla olan hizmetlere dayalı doktorluk, hemşirelik ve öğretmenlik gibi mesleklere özgü bir sorunu tanımlamak için kullanılmıştır (Çavuş, Çavuş, Gök ve Kurtay; 2007: 98). "Freudenberger (1974), tükenmişliği insanlarla yakın ilişki kurulan işlerde çalışanlar arasında görülen enerji tükenmesi, güç kaybı ve karşılanmayan istekler sonucu duygusal tükenme ile sonuçlanan mesleksel bir strese ve buna bağı olarak başarısızlık, yıpranma, aşıı yükleme ile ortaya çıkan enerji ve güç kaybı veya karşılanamayan isteklerin ortaya çıkardığı bireyin iç kaynaklarında ve enerjisinde tükenme durumu" olarak tanımlamıştır (Üngüren, Doğan, Özmen ve Tekin; 2010: 2923).

Meier (1984: 213) tükenmişliği, "Işsten değer elde etme gerginliği sebebiyle azalan beklenti durumu" olarak tanımlamış, Shirom ve Ezrachi (2003: 84) ise tükenmişliği çalışanın işten kaynaklanan stresten dolayı olumsuz duygusal tepkisi olarak ifade etmişlerdir (Akt.: Deliorman, Boz, Yiğit ve Yıldız; 2009: 79). Neden kaynaklanırsa kaynaklansın tükenmişlik, kişiyi özel yaşamında olduğu gibi iş yaşamında da etkileyerek başarılı olmasını engelleyebilmektedir Meydan, Şeşen ve Basım; 2011: 47).

Tükenmişlik, Maslach Tükenmişlik Envanterini geliştiren Christina Maslach'a göre "İşi gereği insanlarla yoğun bir iliş̧i içerisinde olanlarda görülen duygusal tükenme, duyarsızlaşma, ve düşük kişisel başarı hissi" olarak tanımlamıştır (Budak ve Sürgevil, 2005: 96).

Chiu ve Tsai (2006) tükenmişliği, işyerinde stres yaratan ve stresle baş etmeyi zorlaştıran psikolojik ve fiziksel bir rahatsızlık belirtisi olarak ifade etmişlerdir. Tükenmişliğin, genellikle çalışanın enerjisi, zamanı ve kaynakları ile ilgili aşırı taleple karşılaşt̆ğında ve bunun üstesinden gelemediğinde, özellikle insanlarla bire bir karşılıklı ilişki içerisinde çalışan kişilerde ortaya çıktı̆ını ifade etmişlerdir. Genellikle iş talebi, fiziksel veya psikolojik çaba gerektirdiği için çalışanların tükenmişliğine neden olmaktadır. Kim, Shin ve Swanger; (2009) sosyal destek ve özerklik gibi uygulamaların iş talebinin azalmasına yardımcı olduğunu ve aynı zamanda tükenmişlik hissini de azalttı̆̆ın ifade etmişlerdir (Akt.: Sevim, 2011: 73).

\subsection{Duygusal Tükenme}

Duygusal tükenme, beklenmeyen, ani gelişen olumsuz bir durum karşısında kişinin gösterdiği direnci ifade eder (Kahya, 2015: 531). Diğer bir ifade ile çalışanın duygusal olarak tükenmesi ve enerjisinin azalmasını ifade eder. Duygusal olarak tükenmişlik yaşayan çalışanlar işlerine tam olarak yoğunlaşamadıklarından üzerinde biriken olumsuz yükü azaltmak için ilişki kurmak zorunda oldukları kişiler ile en düşük düzeyde ilişki kurarlar. Insanları ayırma, karşılaşılan her kişiye aynı şekilde davranma duygusal tükenme belirtileri arasında sayılabilir (Basım ve Şeşen, 2006). Yıldırım (1996) duygusal tükenmenin daha çok iş ile ilgili stresten kaynaklandığını, duygusal açıdan yoğun bir tempoda bulunan çalışanın, kendisini zorladığını, diğer çalışanların beklentileri altında ezildiğini ve bunun sonucunda duygusal tükenmenin ortaya çıktğını ifade etmiştir (Akt.: Sevim, 2011: 75). 


\subsection{Duyarsızlaşma}

Tükenmişliğin bireyin ruh haliyle ilgili olan boyutudur. Duyarsızlaşma, çalışanların yaptığı işe ve müşterilere yönelik istenmeyen olumsuz davranışlar sergilemesidir. Duyarsızlaşma, bireyin hizmet verdiği müşterilere karşı gereken değeri vermeden, duygudan yoksun tutum ve davranışlar sergilemesidir (Arı ve Bal, 2008: 134). Çalışanların kendilerinden ve yaptıkları işten soğumaları, yabancılaşmaları işten beklentilerini ve heveslerini yitirmeleri, iç ve dış müşterileri önemsememeleri, olumsuz tepkilerde bulunmaları duyarsızlaşmanın belirtileri olarak kabul edilmektedir (Deliorman vd., 2009: 79).

\subsection{Kişisel Başarı Duygusunda Azalma}

Çalışanların kendilerini değerlendirirken olumsuz sonuca ulaşmaları, işte ve birlikte iş yapmak zorunda olduğu kişilerle başarısız ilişki kurmaları ve bu hisse kapılmaları kendilerini başarısız ve yetersiz olarak değerlendirmelerine neden olabilir. Bu durumda çalışan işinde ilerlemediğini aksine gerilediğini düşünerek kendisini suçlu hisseder (Dilsiz, 2006: 14). Kişisel başarının azalması çalışanın kendisini olumsuz yönde değerlendirmesi olarak ifade edilebilir (Budak ve Sürgevil, 2005: 96). Kişisel başarı duygusunda azalma hisseden çalışan kendisine karşı genel bir olumsuzluk ve yetersizlik hisseder, motivasyonu düşer, işi için harcadığı çabanın boşa gittiğini ve örgütüne katkıda bulunamadığı duygusuna kapılabilir (Arı ve Bal, 2008: 134).

\section{4. Çalışan Sessizliği}

Çalışan sessizliği ile ilgili yapılan çalışmalar Hirschman'ın 1970'li yıllardaki çalışmasına kadar uzanmaktadır. Hirschman (1970) çalışmasında sessizliği pasif ancak örgüte bağlılık ile eşdeğer ve olumlu bir tepki olarak ifade etmiştir. 1990'lı yıllarda çalışmalarda "sağır kulak sendromu" ve "sosyal dışlama" gibi konular işlenmiştir. Daha sonra konuşma ve sessizlik, sorun bildirme, örgütsel muhalefet, konu benimsetme, şikâyetçi olma gibi konularda yapılan çalışmalarla genişletilmiş ve örgütsel adalete yönelik yapılan ilk çalışmalarda ise çalışanların sessiz kalmaması üzerine yoğunlaşılmıştır (Yaman ve Ruçlar, 2014: 37).

Sessizlik ile ilgili ile Pinder ve Harlos (2001)'un yaptıkları çalışmalar önemlidir. Morrison ve Milliken (2000: 706) örgütlerde gelişimi önlenemeyen sessizlik sürecini, ortaya çıkışını, devam etmesi ve artmasına neden olan unsurları incelemişlerdir. Pinder ve Harlos (2001) ise algılanan adaletsizliği açıkça konuşup konuşmamaya dair çalışanların kararları üzerindeki etkisini incelemişlerdir. Çalışan sessizliği "değişimi etkileyebilme ya da düzeltebilme yeteneğinde olan insanların, örgütsel durumlara ilişkin konularda, davranışsal, bilişsel ya da duygusal değerlendirme ve düşüncelerini esirgemesi" olarak tanımlanmaktadır (Çakıcı, 2008: 118).

Sessizlik, bir amaca hizmet eden, bilinçli bir şekilde ve kasıtlı olarak yapılan aktif bir davranış olarak değerlendirilmektedir. Örgütlerde çalışan sessizliği görünürde örgüte bağlılık gibi algılansa da aslında çalışanın örgüt ile ilgili olumlu veya olumsuz konularda bilgi sahibi olmasına rağmen bilgileri bilerek ve isteyerek saklaması olarak ifade edilmektedir (Çakıcı, 2010: 9). Ephratt (2008: 1910) ise sessizliği aktif, maksatlı ve stratejik bir davranış olarak nitelendirmiştir. Sessizliğin içinde derin ve gizli anlamlar taşıyan mesajların bulunabildiğini, çalışanların "sessiz" kalarak da iletmek istedikleri mesajları ilgili makamlara ve kişilere iletebildiklerini ve iletilen bu mesajların yöneticiler tarafindan doğru okunması ve anlaşııması gerektiğini belirtmişlerdir (Yaman ve Ruçlar, 2014: 37).

Örgütlerde çalışan sessizliği, örgütsel iletişim ile yakın ilişki içindedir. Çalışan sessizliği örgüt içindeki iletişimde aksaklıklar yaşandığının ve iletişimdeki yetersizliğin bir ifadesi olarak değerlendirilebilir. İletişim sisteminin sağlıklı işlemediği örgütlerde başarıdan söz etmek çok zordur. Çalışanların sessizlik davranışlarına yönelik sergiledikleri tutumları, örgütün sağlıklı bir iletişim sisteminin ve olumlu bir iletişim atmosferinin olup olmadığı yönünde bilgi verir (Aktaş ve Şimşek, 2015: 207). Çalışanlar gönüllü olarak yukarı doğru örgütün üst seviyesindeki yöneticilerle iletişimlerinde öneriler, endişeler, problemler hakkında bilgilendirme veya iş ile ilgili düşüncelerini ifade ederlerken, bazı girdiler geri çekildiğinde sessiz kalarak örgütleri için yararlı olabilecek bilgileri paylaşmazlar (Morrison, 2014; 173). 
Çalışan sessizliği işe yönelik bilgilerin, çeşitli nedenlerden ötürü maksatlı olarak tutulması, paylaşılmaması veya verilmemesi şeklinde ifade edilmektedir (Pinder ve Harlos, 2001; Van Dyne, Ang ve Botero; 2003). Bazı temel nedenlerden kaynaklanan sessizlik kasıtlı olarak kullanılabilir, bu durum sessizliği sadece fikirlerin ifade edilmemesi ile ilgili sessizlikten ayıran temel bir neden olarak belirtilmiştir (Brinsfield, 2009: 2). Çalışan sessizliği "çalışanların işle ilgili konular ve sorunlar hakkındaki bilgilerini, görüşlerini ve kaygılarını bilinçli olarak yönetimle paylaşmamaları, kendilerine saklamaları" (Morrison ve Milliken, 2000: 707), "çalışanların örgütsel sorunlar hakkındaki görüşlerini ve endişelerini esirgemeleri" şeklinde ifade edilmektedir (Özdemir ve Uğur, 2013: 258; Çakıcı, 2007: 149).

Örgüt yönetimleri zaman zaman çalışanları isteyerek veya farkında olmadan sessiz kalmaya itebilmektedir. Yöneticilerin öneri ve eleştirilere olumsuz yaklaşımı çalışanların kendilerini çekmelerine neden olabilir. Öneri ve eleştirilerini ifade etmekle herhangi bir sonuca ulaşamayacağı hissine kapılan çalışanlar sessizliği tercih edebileceklerdir (Özdemir ve Uğur, 2013: 258). Bunun yanında yöneticilerin iyi niyetli olmayan davranışlarının da çalışanları duygusal tükenmişliğe ittiği ve sessizleştirdiği belirtilmiştir (Xu, Loi ve Lam; 2015: 763). Van Dyne vd., (2003: 1359) çalışan sessizliğini kabullenici, koruyucu ve korunma olmak üzere üç türde incelemişlerdir.

Çalışan sessizliği örgütlerde çoğunlukla çalışanlar arasında iş yerinde bulunmama ve işten ayrılma gibi olumsuz davranışlara neden olan ve tatminsizlik yaratması bakımından örgütün işleyişine zarar veren önemli bir konudur. Çalışan sessizliğinin sonuçları arasında yenilik hareketlerinin ve proje üretiminin azalması, düşük moral ile kalitesiz ve hatalı ürün sıralanabilir. Sürekli sessizlik bazı çalışanların iş kalitesi ile ilgilenmemelerine neden olabilir (Bagheri, Zaren ve Aeen; 2012). Çalışan sessizliğine neden olan faktörleri Richard (2003); korku, huzursuzluk, konuşmak için yeterli imkan olmaması, örgütsel politika imkanlarının yetersiz olması, iş arkadaşları ve etik sorumluluklarla ilgili sığ düşünceler şekilde sıralamıştır. Çalışan sessizliğinin sadece örgüte değil, örgüt ile birlikte çalışanlara da zarar vereceği ifade edilebilir (Akt.: Çınar, Karcıoğulları ve Alioğulları; 2013: 316).

Çalışan sessizliği iş ile ilgili konular, örgütün izlediği yönetim politikaları, tecrübesizlik, yalnızlaştırma ve ilişkilerin bozulması endişesi boyutları ile incelenmiştir. Çalışan sessizliğinin nedenleri çalışanların yöneticilerine güvenmemesi, konuşmanın riskli görülmesi, dışlanma ve ilişkilerin bozulacağı korkusu gibi dört ana başık altında incelenmektedir (Gül ve Özcan, 2011: 113). Yapılan bir çalışmada çalışanların sessizliğinin beklenti ve kişilikten kaynaklandığı; çalışanların kendilerine zarar gelebileceği düşüncesi, yöneticiyi sorumlu olarak görme, kendi yeteneklerini sorgulama, yöneticilerin ilgisiz kalabileceğini öngörme, konuşma için zamanlamanın uygun olmadığını düşünmenin çalışanların sessiz kalmalarına neden olabileceği belirtilmiştir (Bisel ve Arterburn, 2012; 217).

Örgüt politikasında çalışan sessizliğinin ardındaki nedenleri araştıran bir çalışmada örgüt politikaları ile çalışan sessizliği arasında olumlu ilişki olduğu sonucuna ulaşılmıştır (Khalid ve Ahmed, 2016; 174).

Özgan ve Küleçi (2012: 44) çalışan sessizliğini kişisel, yönetsel ve örgütsel olmak üzere üç gruba dayandığını ifade etmişlerdir. Kişisel nedenlerin; kişilik, tutum, içinde yetiştiği çevre ve tecrübelerinden oluştuğunu; yönetsel nedenlerin yöneticilerin tutumu, kişiliği ve iletişim tarzlarından oluştuğunu; örgütsel nedenlerin ise örgüt kültürü, iklimi ve teşkilat yapılanması gibi konulardan oluştuğunu ifade etmişlerdir. Adaletsizlik kültürü, sessizlik iklimi, örgütsel iletişim ve örgüt kültürü gibi faktörler de örgütsel nedenler arasında sıralanmıştır (Kahya, 2015: 529).

\section{5. Örgütsel Adalet Algısı, Tükenmişlik Düzeyi ve Çalışan Sessizliği Arasındaki İlişkiler}

\section{1. Örgütsel Adalet İle Tükenmişlik Düzeyleri Arasındaki İlişkiler}

Çalışanların örgütsel adalet algılarının tükenmişlik düzeyleri üzerinde etkili olabileceği değerlendirilmektedir. Olumlu adalet algısı tükenmişlik duygusuna ilişkin eğilimleri engelleyerek çalışanların işe ve örgüte olan bağlılıklarını artırabilir. Böylece çalışanlar bilgi ve tecrübelerini örgüt için kullanarak, örgütün başarısı ve verimliliği üzerinde olumsuz etkileri olan davranışlar sergilemekten kaçınabilirler. Kaliteli çalışanların örgütte istihdam edilmesi, önemli rekabet avantajı sağlayabilmektedir. Bu avantajın sağlanması 
için yöneticilerinin çalışanları cesaretlendirecek, onları harekete geçirebilecek, tükenmişlik duygularını azaltabilecek yönde davranışlar sergilemeleri gereklidir (Yeniçeri vd., 2009: 84).

Laschinger ve Fida (2014: 234) yaptıkları çalışmada yönetimin çalışanlara verdiği desteğin ve kişinin kendi zihninde oluşan dayanak ve çözümlerin çalışanların tükenmişlik, iş tatminsizliği ve akıl sağlığı üzerindeki koruyucu ve önleyici rolünü desteklediği sonucuna ulaşmışlardır.

Whiteside ve Barclay (2013: 251) kabullenici sessizliğin (sessizlik) genel adalet algısı ile duygusal tükenme, psikolojik ve fiziksel geri çekilme ve performans ile kısmen veya tamamen aracılık rolü olduğunu belirtmişlerdir.

Kamu kurumlarında Meydan vd. (2011: 54) tarafindan yapılan araşttrma sonucuna göre örgütsel adalet ile tükenmişlik algısı arasında olumsuz yönde etki olduğu, çalışanın örgütsel adalet algısına sahip olmasının tükenmişlik duygusunu azalttğı yönünde sonuca ulaşmıştır. Benzer şekilde Şeşen (2011: 80) öğretmenler üzerinde yapmış olduğu araştırmada dağıtımsal adalet ve etkileşimsel adaletin tükenmişlik üzerinde etkili olduğunu, işlemsel adaletin ise etkisi olmadığı sonucuna ulaşmıştır. Hur vd. (2014: 195) örgütsel adalet boyutlarının duygusal tükenme üzerinde aracılık rolünün olduğunu belirtmişlerdir.

Bankacılık sektöründe Sökmen, Bilsel ve Ergin (2013: 5) tarafindan yapılan çalışmada banka çalışanlarının olumlu örgütsel adalet algılarının performansları ve motivasyonları üzerinde olumlu yönde etkili olduğu sonucuna ulaşmışlardır. Bu olumlu sonuçların çalışanların tükenmişlik algıları üzerinde ise olumsuz etki yapabileceği diğer bir ifade ile tükenmişlik hissine kapılmayabilecekleri ifade edilebilir.

Yıldırım vd. (2012: 340) yaptıkları çalışmada eğitim müfettişlerinin örgütsel adalet algıları ile duygusal tükenmeleri arasında negatif yönlü anlamlı, duyarsızlaşma ile negatif yönlü ve düşük düzeyli bir ilişki olduğunu, kişisel başarı duygusu ile negatif yönlü ancak anlamlı bir ilişki olmadığı sonucuna ulaşmışlardır.

Balaban ve Konyalı (2016: 203) yapmış oldukları çalışmada tükenmişliğin örgütsel adaletin anlamlı bir yordayıcısı ve negatif yönlü etkisi olduğunu belirlemişlerdir. Duygusal tükenmenin dağıtımsal, işlemsel ve etkileşimsel adalet üzerinde negatif etkisinin olduğunu, duyarsızlaşma boyutunun işlemsel ve etkileşimsel adalet üzerinde negatif etkisinin olduğunu ancak kişisel başarı boyutu ile anlamlı bir ilişkinin olmadığı sonucuna ulaşmışlardır.

Yeniçeri vd. (2009: 83) tarafindan yapılan çalışmada dağıtımsal ve etkileşimsel adalet algılarıyla duygusal tükenme arasında olumsuz yönlü bir ilişki, işlemsel adalet ile duygusal tükenme arasında ise olumlu yönlü ilişki olduğunu belirlemişlerdir. Pelit ve Bozdoğan (2014: 55) yaptıkları çalışmada örgütsel adalet ve alt boyutlarının duygusal tükenme ve duyarsızlaşma ile negatif, kişisel başarı duygusunda azalma hissi ile pozitif ilişkisi olduğu sonucuna ulaşmışlardır.

Köse (2014: 100) dağıtımsal adaletin duyarsızlaşma ve kişisel başarıyı negatif yönde etkilediğini; işlemsel adaletin duygusal tükenme ve duyarsızlaşmayı negatif yönde etkilediğini, etkileşimsel adaletin kişisel başarıyı negatif yönde etkilediğini, dağıtımsal adaletin duygusal tükenme, işlemsel adaletin kişisel başarıda azalma hissi, etkileşimsel adaletin duygusal tükenme ve duyarsızlaşma üzerinde etkisinin olmadığı sonucuna ulaşmıştır.

Loera, Gattino ve Converso (2013) tarafindan İtalya'da bir sağlık kuruluşunda yapılan çalışmada tükenmişlik üzerinde örgütsel adalet ve sosyal desteğin etkili olduğu sonucuna ulaşmışlardır.

Uluköy (2014: 213) kamu ve özel sağlık kurumlarında görev yapan çalışanlar üzerinde yaptığı araştırmada örgütsel adalet algısı ile tükenmişlik arasında olumsuz yönlü bir ilişki olduğu sonucuna ulaşmıştır. Bu bilgiler ışığında örgütsel adalet ve tükenmişlik arasındaki ilişkiyi belirlemekamacıyla oluştulan hipotezler şu şekildedir;

H1: Çalışanların dağıtımsal adalet algıları duygusal tükenme düzeylerini olumsuz etkiler.

H2: Çalışanların dağıtımsal adalet algıları duyarsızlaşma düzeylerini olumsuz etkiler.

H3: Çalışanların dağıtımsal adalet algıları kişisel başarıda azalma hislerini olumsuz etkiler. 
H4: Çalışanların işlemsel adalet algıları duygusal tükenme düzeylerini olumsuz etkiler.

H5: Çalışanların işlemsel adalet algıları duyarsızlaşma düzeylerini olumsuz etkiler.

H6: Çalışanların işlemsel adalet algıları kişisel başarıda azalma hislerini olumsuz etkiler.

H7: Çalışanların etkileşimsel adalet algıları duygusal tükenme düzeylerini olumsuz etkiler.

H8: Çalışanların etkileşimsel adalet algıları duyarsızlaşma düzeylerini olumsuz etkiler.

H9: Çalışanların etkileşimsel adalet algıları kişisel başarıda azalma hislerini olumsuz yönde etkiler.

\section{2. Örgütsel Adalet Algısı İle Çalışan Sessizliği Arasındaki İlişkiler}

Örgütsel faktörlere bağlı olarak olumlu yönlü adalet algısı çalışanların duygusal tükenmelerini azaltmakta, duyarsızlaşmalarını önleyebilmektedir. Adalet algısı ile örgütsel vatandaşlık arasındaki ilişki dikkate alındığında, çalışanların örgütte adil olmayan bir davranış veya uygulama fark ettiklerinde, gönüllü davranışlarını azalttıkları ya da gizledikleri ifade edilebilir (İşbaşı, 2001). Bu gizleme eğilimi beraberinde sessizliği getirmektedir. Zira çalışan sessizliğinin alt boyutları dikkate alındığında koruma ve korunma amaçlı sessizliğin bu aşamada devreye girdiği söylenebilir.

Wang ve Jiang (2015: 211) tarafindan yapılan araştırmada kötü yöneticilerin çalışanların etkileşimsel adalet algılarını olumsuz yönde etkilediğini, etkileşimsel adalet algısı ile çalışan ses/sessizliği arasında ise olumlu yönde ilişki olduğu sonucuna ulaşmışlardır. Duan, Lam, Chen ve Zhong (2010: 1287) yöneticilerin adil olmasının çalışan sessizliği üzerinde negative etkisi olduğunu belirtmişlerdir. Tangırala ve Ramanujam (2008: 37) tarafindan yapılan çalışmada ise işlemsel adalet ikliminin yüksek olduğu örgütlerde yapılan örgütsel uygulamaların çalışanların sessizliklerini engellediği ve sessizlik düzeylerinin daha düşük olduğu sonucuna ulaşmışlardır.

Tulubaş ve Celep (2012) yaptıkları çalışma ile algılanan adaletin fakülte çalışanlarının sessizliğine önceden işaret ettiğini tespit etmişler, üstlere duyulan güvenin, algılanan adalet ve örgüt üyelerinin sessizliğini belirleyen işlemsel adalet ile bir bağ oluşturduğunu ortaya koymuşlardır. Ünlü vd. (2015) öğretmenlerin örgütsel adalet boyutları algıları ile savunmacı sessizlikleri arasında olumsuz yönlü, korumacı ve kabullenici sessizlikleri ile olumlu yönlü ilişki olduğunu belirlemişlerdir.

Arı ve Bal (2008: 138) tarafindan yapılan çalışmada beş faktör kişilik özelliklerinden olan nevrotizm ve içedönüklüğün tükenmişliğin her üç boyutu ile de ilişkili olduğu sonucuna ulaşmışlardır. İçedönük kişilik özelliğine sahip çalışanların daha fazla tükenmişlik yaşayabilecekleri, örgütsel uygulamalar karşında daha sessiz kalabilecekleri dikkate alındığında çalışan sessizliğinin daha yüksek olabileceği söylenebilir. Bu bilgilerden hareketle örgütsel adalet algısı ile çalışan sessizliği arasındaki ilişkiyi belirlemek amacıyla oluşturulan hipotezler şu şekilde ifade edilebilir;

H10: Çalışanların dağıtımsal adalet algıları çalışan sessizliğini olumsuz yönde etkiler.

H11: Çalışanların işlemsel adalet algıları çalışan sessizliğini olumsuz yönde etkiler.

H12: Çalışanların etkileşimsel adalet algıları çalışan sessizliğini olumsuz yönde etkiler.

\subsection{Tükenmişlik ile Çalışan Sessizliği Arasındaki ilişkiler}

Sessizliğin mutlaka örgütsel faktörlerden kaynaklanamayacağı, çalışanların kişisel değerlendirmelerinin de sessizliğin biçimini belirleyebileceği ifade edilmiştir. Çalışanların duygusal tükenmişlik düzeyleri arttkç̧a, kabullenici ve savunmacı sessizlikliğin arttı̆̆, ilişkisel sessizliğin ise azaldığı belirlenmiştir. Kamu çalışanları üzerinde yapılan araştrrmada çalışan sessizliğinin tükenmişlik üzerinde etkili olduğu sonucuna ulaşılmıştır (Aktaş ve Şimşek, 2015: 226).

Kahya (2015: 523) tarafindan akademisyenler üzerinde yapılan araştırmada çalışan sessizliği ile tükenmişlik arasında anlamlı, olumlu yönde ilişkinin olduğu belirlenmiştir. Çalışan sessizliğinin çalışan tükenmişliğini olumlu yönde etkilediği sonucuna ulaşılmıştır. 
Örgüt çalışanlarının yüksek seviyede stres altında olmaları, fiziksel rahatsızlıklarla birlikte istenmeyen iş kazalarına, sağlık harcamalarına, çalışanların işten ayrılmalarına, işyerinde çatışmaların ve tükenmişliğin artmasına neden olabileceği ifade edilebilir. Yüksek seviyede stresin işgören devir hızını ve örgütten ayrılmaları arttırabileceği gibi çalışan sessizliğini de arttrabileceği sonucuna ulaşılabilir (Kılıç, Tunç, Saraçlı ve Kılıç; 2013: 26).

Bireylerin iletişim kurmayarak sessiz kalmasına neden olan bir çalışma ortamının zamanla çalışanlarda engellenmişlik, çaresizlik, kimsesizlik gibi olumsuz duyguların oluşmasına ve enerjilerinin tükenmesine yol açabileceğini belirten Tikici, Deri ve Kalkın (2011: 259), KOBi'lerde yaptıkları araştırmada çalışan sessizliği ile duygusal tükenmişlik arasında pozitif yönlü ve güçlü bir ilişki olduğu sonucuna ulaşmışlardır. Yöneticilerin iyi niyetli olmayan davranışlarının çalışanları duygusal tükenmişliğe ittiği ve sessizleştirdiği belirtilmiştir (Xu vd., 2015: 763). Öğretmenler üzerinde yapılan bir araştırmada çalışan sessizliği ile tükenmişlik düzeyleri arasında olumlu yönlü ancak anlamlı bir ilişki olmadığı belirlenmiştir (Çiftçi, Öztürk ve Meriç; 2015: 996).

Akın ve Ulusoy (2016: 46) tarafindan akademisyenler üzerinde yapılan çalışmada, akademisyenlerin sessizlik seviyelerinin orta düzeyde tükenmişlik seviyelerinin ise düşük olduğunu, sessizlik ile tükenmişlik arasında pozitif yönlü ilişki olduğunu aynı zamanda sessizlik değerlerinin tükenmişlik algılarını da etkilediğini belirtmişlerdir.

Tahmasebi vd. (2013: 272) çalışanın yapmak istediği ile yapmak zorunda oldukları arasındaki farklılığın beraberinde çatısmayı getirdiğini, bu çatışmanın en önemli etkenlerinden birisinin ise örgütteki baskın sessizlik kültürü olduğunu ifade edilmişlerdir. Yaptıkları araştırmada çalışan sessizliğinin tükenmişlik için önemli bir açıklayıcı olduğunu, sessizlik ile tükenmişlik arasında pozitif ve güçlü bir ilişki olduğu sonucuna ulaşmışlardır. Duygusal tükenmişlik ve duyarsızlaşma ile çalışan sessizliği arasında doğrudan ve anlamlı, kişisel başarı ile arasında herhangi bir ilişki olmadığı sonucuna ulaşmışlardır. Bu bilgilerden hareketle tükenmişlik boyutları ile çalışan sessizliği arasındaki ilişkiyi belirlemek amacıyla oluşturulan hipotezler şu şekilde ifade edilebilir:

H13: Çalışanların duygusal tükenme düzeyleri çalışan sessizliğini olumlu yönde etkiler.

H14: Çalışanların duyarsızlaşma düzeyleri çalışan sessizliğini olumlu yönde etkiler.

H15: Çalışanların kişisel başarıda azalma hissi çalışan sessizliğini olumlu yönde etkiler.

\section{Yöntem}

\subsection{Araştırmanın Yöntemi}

Çalışanların örgütsel adalet algılarının tükenmişlik düzeyi ve çalışan sessizliği arasındaki ilişkileri incelemek amacıyla örneklem sayısı, ortalama ve standart sapma değerlerini içeren betimsel istatistik işlemleri; örgütsel adalet, tükenmişlik düzeyleri ve çalışan sessizliği boyutları ile bu boyutların alt boyutlarının güvenirlik analizleri ve faktör analizleri yapılmış, korelasyon analizi yapılarak ilişkileri incelenmiş, regresyon analizileri ile bağımsız değişkenlerin bağımlı değişken üzerindeki etkileri incelenmiş ve ulaşılan sonuçlar yorumlanmıştır.

Boyutların birbiri üzerindeki etkisini belirlemek üzere örgütsel adalet alt boyutlarının (dağıtımsal, işlemsel ve etkileşimsel adalet) bağımsı değişken, tükenmişlik düzeyi alt boyutları (duygusal tükenme, duyarsızlaşma ve kişisel başarıda azalma hissi) bağımlı değişken olarak alınmış ve regresyon analizleri yapılmıştır. Regresyon analizi ile örgütsel adalet alt boyutları, tükenmişlik düzeyi alt boyutları ile çalışan sessizliği arasındaki ilişkilerin yönü ve kuvveti belirlenmeye çalışılmıştır. Örgütsel adalet alt boyutları bağımsız, çalışan sessizliği boyutu bağımlı değişken olarak alınmış ve regresyon analizi yapılmıştır. Daha sonra tükenmişlik düzeyi alt boyutları bağımsız, çalışan sessizliği boyutu ise bağımlı değişken olarak alınmış ve regresyon analizi yapılmıştır. 


\subsection{Araştırmanın Modeli}

Araştırmada örgütsel adalet algısı alt boyutları ile tükenmişlik düzeyi alt boyutları ve çalışan sessizliği boyutu ile ilişkilerini belirlemeye yönelik oluşturulan model Şekil 1'de sunulmuştur. Örgütsel adalet alt boyutlarının her birinin tükenmişliğin alt boyutları ile örgütsel adalet alt boyutlarının çalışan sessizliği ile ve tükenmişlik alt boyutlarının çalışan sessizliği ile ilişkileri modelde yer almaktadır.

Şekil 1. Araştırmanın Modeli

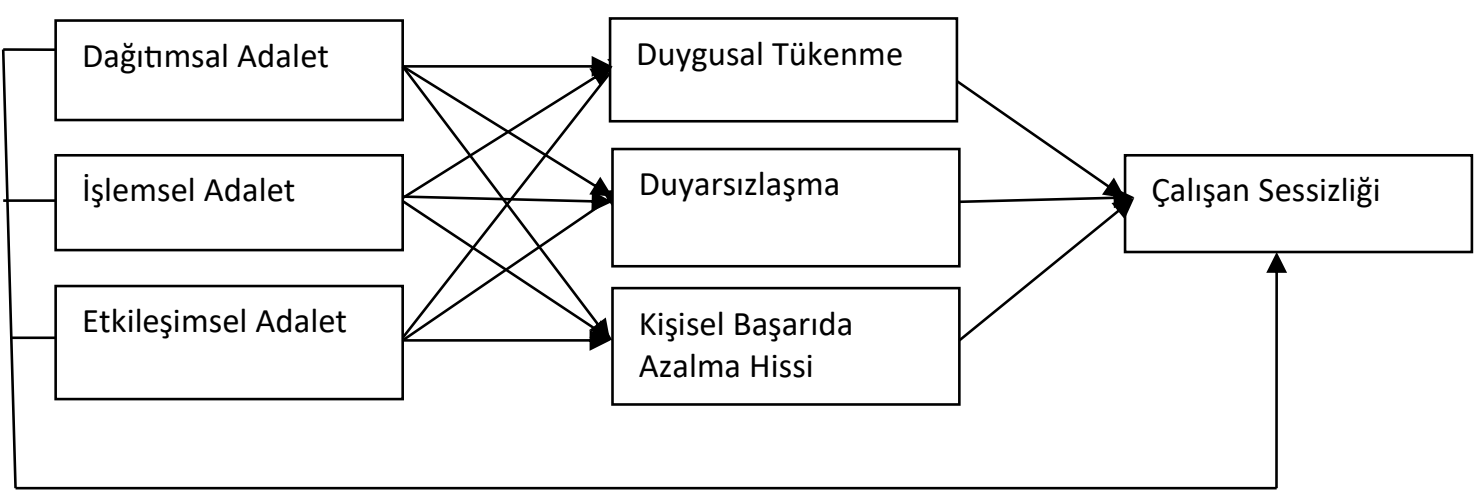

\subsection{Evren ve Örneklem}

Araştırma için imalat sektöründe aynı iş kolunda İzmir, Bursa ve Balıkesir illerinde faaliyet gösteren sanayi ve ticaret odalarına kayıtlı olan örgütler arasından kolayda örneklem yöntemi kullanılarak belirlenmiş, belirlenen örgütlerle irtibata geçilmiş, çalışmanın amacı ve uygulanacak soru formları hakkında bilgilendirme yapılmıştır. Görüşme yapılan örgütlerden üç tanesi çalışma için onay vermişlerdir. Araştırmanın evrenini İzmir, Bursa ve Balıkesirde aynı iş kolunda faaliyet gösteren ve çalışmayı kabul eden üç imalat örgütünün 396 çalışanı oluşturmaktadır.

Anket uygulamasının yapıldığı üç örgütten İzmir'de faaliyet gösteren A örgütünde 168, Bursa'da faaliyet gösteren B örgütünde 101 ve Balıkesir'de faaliyet gösteren C örgütünde ise 127 olmak üzere toplam 396 kişi çalışmaktadır. A örgütünden 51 çalışan, B örgütünden 52 çalışan ve $C$ örgütünden ise 120 çalışan anket uygulamasına katılmıştır. Diğer çalışanlar izin, vardiya vs. nedenlerle araştırmaya katılmamışlardır. Araştırmaya katılan her örgütteki çalışanlara Mayıs-Haziran 2016 tarihlerinde örgüt yönetimi tarafindan belirlenen zamanda önce bilgilendirme yapılmış ardından çalışanların tamamına bir defada anket uygulaması yapılmış ve anketler geri toplanmıştr. Uygulama sonrasında 223 anket elde edilmiş, yapılan incelemede bu anketlerden 14 adedinin eksik veya uygun doldurulmadığı belirlenmiş, 209 adedi analize dahil edilmiştir. Kolayda örneklem ile toplanan verilerin evreni temsiliyet yetkisi çok kısıtıdır. Bu nedenle yapılan analizde sadece örneklem açısından değerlendirilecektir.

Anket uygulamasından elde edilen verilen SPSS 21.0 paket programına aktarılmıştır. Demografik özelliklere yönelik yapılan analizler neticesinde elde edilen bilgiler Tablo 1'de sunulmuştur. Buna göre ankete katılan çalışanların \%71,8'i (150 kişi) 21-40 yaş arası çalışanlardan oluşmaktadır. Çalışanların \% 42,5'ini oluşturan 89 kişinin üretim kısmında çalıştı̆ı, üniversite mezunu çalışanları toplam çalışanların \% 32,5'ini oluşturduğu, Çalışanların \% 40,2'sinin (84 kişi) örgütte 1-5 yıl arası çalıştığı belirlenmiştir. Çalışanların büyük kısmının \% 36,4'ünün örgütlerinde işçi statüsünde çalıştkkları belirlenmiştir. 
K. Erogluer - R. C. Erselcan

Tablo 1. Katılımcılara Illişkin Tanımlayıcı Bilgiler

\begin{tabular}{|c|c|c|c|c|c|c|c|}
\hline \multicolumn{2}{|c|}{ DEMOGRAFIK ÖZELLIKLER } & \multirow{2}{*}{$\begin{array}{r}\text { Sayı } \\
51\end{array}$} & \multirow{2}{*}{$\begin{array}{c}\text { Yüzde } \\
24,4\end{array}$} & \multicolumn{2}{|c|}{ DEMOGRAFIK ÖZELLIKLER } & \multirow{2}{*}{$\begin{array}{r}\text { Sayı } \\
30\end{array}$} & \multirow{2}{*}{$\begin{array}{r}\text { Yüzde } \\
14,3\end{array}$} \\
\hline \multirow{3}{*}{ 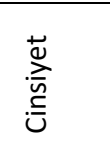 } & Kadın & & & \multirow{6}{*}{ 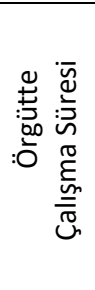 } & 1 yıldan az & & \\
\hline & Erkek & 158 & 75,6 & & $1-5 \mathrm{yll}$ & 84 & 40,2 \\
\hline & Toplam & 209 & 100,0 & & 6-10 yıl & 48 & 23,0 \\
\hline \multirow{3}{*}{ 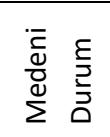 } & Evli & 160 & 76,6 & & $11-15 \mathrm{yll}$ & 24 & 11,5 \\
\hline & Bekar & 49 & 23,4 & & 16 yıl ve üstü & 23 & 11,0 \\
\hline & Toplam & 209 & 100,0 & & Toplam & 209 & 100,0 \\
\hline \multirow{6}{*}{$\underset{⿱ 乛}{\infty}$} & 20 Yaş ve altı & 3 & 1,4 & \multirow{11}{*}{ 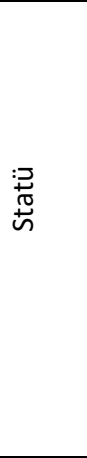 } & Mühendis & 15 & 7,2 \\
\hline & $21-30$ arası & 57 & 27,3 & & İşçi & 76 & 36,4 \\
\hline & $31-40$ arası & 93 & 44,5 & & Büro Çalışanı & 29 & 13,8 \\
\hline & $41-50$ arası & 38 & 18,2 & & Kalfa & 22 & 10,5 \\
\hline & 51 ve üstü & 18 & 8,6 & & Usta & 16 & 7,7 \\
\hline & Toplam & 209 & 100,0 & & Ustabaşı & 3 & 1,4 \\
\hline \multirow{9}{*}{ 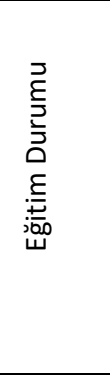 } & Okuryazar & 2 & 1,0 & & Alt Kademe Yön. & 15 & 7,2 \\
\hline & ilkokul & 41 & 19,6 & & Orta Kad. Yön. & 12 & 5,7 \\
\hline & Ortaokul & 32 & 15,3 & & Üst Kad. Yön. & 1 & 0,5 \\
\hline & Lise & 46 & 22,0 & & Diğer & 20 & 9,6 \\
\hline & MYO & 10 & 4,8 & & Toplam & 209 & 100,0 \\
\hline & Üniversite & 68 & 32,5 & \multirow{11}{*}{ 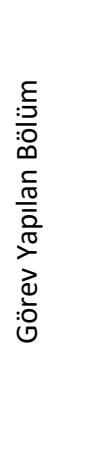 } & Üretim & 89 & 42,5 \\
\hline & Lisansüstü & 8 & 3,8 & & Yönetim Böl. & 6 & 2,9 \\
\hline & Diğer & 2 & 1,0 & & Satış & 16 & 7,7 \\
\hline & Toplam & 209 & 100,0 & & ARGE & 10 & 4,8 \\
\hline \multirow{7}{*}{ 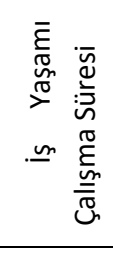 } & 1 yıldan az & 14 & 6,7 & & ik & 7 & 3,4 \\
\hline & $1-5 \mathrm{yll}$ & 38 & 18,2 & & Muhasebe & 14 & 6,7 \\
\hline & 6-10 yıl & 49 & 23,4 & & Ambalaj & 18 & 8,6 \\
\hline & $11-15$ yıl & 30 & 14,4 & & Depolama & 21 & 10,0 \\
\hline & 16 yıl ve üstü & 78 & 37,3 & & Güvenlik & 12 & 5,7 \\
\hline & Toplam & 209 & 100,0 & & Diğer & 16 & 7,7 \\
\hline & & & & & Toplam & 209 & 100,0 \\
\hline
\end{tabular}

\subsection{Veri Toplama Araçları}

Araştırmada veri toplamak üzere geliştirilen soru formu dört bölümden oluşmaktadır. Birinci bölümde örgütsel adalet algısını belirlemeye yönelik 20 ifade, ikinci bölümde çalışan sessizliğini belirlemeye yönelik 6 ifade, üçüncü bölümde tükenmişlik düzeyini belirlemeye yönelik 22 ifade ve son bölümde demografik özelliklere yönelik 8 ifade olmak üzere toplam 56 ifade yer almaktadır. Demografik özellikler hariç diğer ölçeklerdeki tüm ifadeler 5 'li likert ölçeğine uygun olarak " 1 Kesinlikle Katılmıyorum" ile " 5 Tamamen Kathlıyorum" şeklinde oluşturulmuştur.

Yapılan çalışmalarda genellikle örgütsel adalet algısının alt boyutları dağıtım adaleti, süreç adaleti ve etkileşim adaleti olarak (Batool, 2013: 648) üç boyut halinde incelenmiş olduğu görülmektedir (Meydan vd., 2011: 46). Colquitt, Conlon, Porter ve Wesson; (2001) tarafindan geliştirilen örgütsel adalet ölçeği toplam 20 ifadeden oluşmaktadır. Colquitt'in adalet ölçeği Ömür Timurcanday Özmen, Yasemin Arbak ve Pınar Süral Özer'in (2007: 25) “Adalete Verilen Değerin Adalet Algıları Üzerindeki Etkisinin Sorgulanmasına İlişkin Bir Araştırma" isimli çalışmalarında Türkçeye uyarlayarak kullanmışlar, ölçeğin güvenirlik ve geçerlilik değerleri oldukça yüksek çıkmıştır. Bu çalışmada Çöp (2008: 147)'ün çalışmasında da yer alan aynı üç boyutlu örgütsel adalet ölçeği kullanılmıştır.

Tükenmişliği Kristensen, Borritz, Villadsen ve Christensen (2005: 197) kişisel tükenmişlik, işle ilgili tükenmişlik ve müşteri ile ilgili tükenmişlik olmak üzere üç boyutta incelerken, Maslach ve Jackson (1981) tükenmişlik kavramını duygusal tükenme, duyarsızlaşma ve kişisel başarıya ilişkin duyguları ayıran üç boyutta 
incelemişlerdir (Yıldız, Yalavaç ve Meydan; 2013: 158). Christina Maslach ve Susan Jackson tarafindan geliştirilen, Türkçe uyarlaması, geçerlik ve güvenilirlik çalışması Canan Ergin tarafindan yapılmış olan "Maslach Tükenmişlik Ölçeği" toplam 22 maddeden oluşmaktadır. Yapılan bu çalışmada tükenmişlik düzeylerini ölçmek üzere Budak ve Sürgevil (2005: 98) çalışmasında üç boyutlu olarak yeralan ölçek aynı şekilde kullanılmıştır.

Örgütlerde seslilik ve sessizliğin aynı anda bir arada bulunabileceği (Van Dyne vd. 2003; Morrison 2011) gözönüne alındığında, Çetin ve Çakmakçı (2012: 8) tarafindan Türkçeye çevrilen, geçerlilik ve güvenirlik testi sonuçları yüksek çıkan tek boyutlu örgütsel seslilik veya sessizlik ölçeği ifadelerin tüm çalışanlarca kolaylıkla anlaşılır olması nedeniyle bu çalışmada kullanılmıştır.

\subsubsection{Güvenirlik Analizleri}

Çalışmada kullanılan ölçeklerin güvenirliklerini belirlemek için güvenirlik analizileri yapılmıştır. Örgütsel adalet, tükenmişlik ve çalışan sessizliği boyutları ile örgütsel adalet ve tükenmişlik alt boyutlarının Cronbach Alpha değerleri Tablo 2'de sunulmuştur. Kullanılan ifadelere yönelik yapılan güvenirlik analizi sonucunda örgütsel adalet boyutu bir bütün olarak 0,941; alt boyutlardan işlemsel adalet alt boyutunun değerinin 0,852 ; dağıtımsal adalet alt boyutunun 0,847 ; etkileşimsel adalet alt boyutunun değerinin ise 0,952 olduğu belirlenmiştir.

Tükenmişlik boyutu bir bütün olarak 0,785; tükenmişlik alt boyutlarından duygusal tükenme alt boyutunun 0,841 ; duyarsızlaşma alt boyutunun 0,733 ve kişisel başarıda azalma hissi alt boyutunun ise 0,780 olduğu belirlenmiştir. Çalışan sessizliği çalışmada bir boyut olarak alınmış, ifadelerin bir bütün olarak cronbach alpha değerinin 0,935 olduğu belirlenmiştir. Elde edilen bu değerlerden çalışmada kullanılan ölçeklerin güvenirliklerinin yüksek olduğu sonucuna ulaşılmıştır.

Tablo 2. Güvenirlik Analizleri

\begin{tabular}{|c|c|c|c|c|c|}
\hline \multicolumn{2}{|c|}{ Boyutlar } & Cronbach Alpha & \multirow{2}{*}{\multicolumn{2}{|c|}{\begin{tabular}{r}
\multicolumn{1}{c}{ Boyutlar } \\
Tükenmişlik
\end{tabular}}} & Cronbach Alpha \\
\hline & ütsel Adalet & 0,941 & & & 0,785 \\
\hline \multirow{3}{*}{ 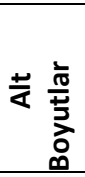 } & İşlemsel Adalet & 0,852 & \multirow{3}{*}{ 荤克 } & Duygusal Tükenme & 0,841 \\
\hline & Dağıtımsal Adalet & 0,847 & & Duyarsızlaşma & 0,733 \\
\hline & Etkileşimsel Adalet & 0,952 & & $\begin{array}{l}\text { Kişisel Başarıda } \\
\text { Azalma Hissi }\end{array}$ & 0,780 \\
\hline & Çalışan Sessizliği & 0,935 & & & \\
\hline
\end{tabular}

\subsubsection{Faktör Analizleri}

Çalışmada kullanılan ölçeklerin faktör analizine uygunluğunu belirlemek üzere önce Kaiser-MeyerOlkin (KMO) testi ve ardından her ölçek için ayrı ayrı faktör analizi yapıımıştır.

Örgütsel adalet ölçeğine yönelik yapılan ilk analizde KMO değeri 0,914 p=0,000 çıkmış, analizde EA4 kodlu "Amiriniz size haksız yorum ve eleştiriler yöneltir mi?" ifadesinin faktör yükü düşük çıktı̆ından EA4 kodlu ifade çıkarılarak analiz tekrarlanmış ve KMO testi değeri 0,915 p=0,000 çıkmıştır. Örgütsel adalet ifadelerinin üç alt boyuta ayrıldığı görülmüş ve elde edilen faktör analizi sonuçları Tablo 3'te sunulmuştur.

Tükenmişlik ölçeği 22 ifadeden ve üç boyuttan oluşmaktadır. Yapılan ilk analizde KMO değeri 0,839; $\mathrm{p}=0,000$ bulunmuş, faktör analizinde KB8 kodlu "Yaptı̆ıım iş sayesinde insanların yaşamına katkıda bulunuyorum" ifadesi ile DT18 kodlu "İ̧̧imde çok fazla çalıştı̆ımı hissediyorum" ifadelerinin faktör yükleri düşük çıktığından analizden çıkarılarak analiz tekrarlanmış, KMO değeri 0,849; $p=0,000$ bulunmuş ve Tablo 4'te faktör yükleri sunulmuştur. 
Tablo 3. Örgütsel Adalet Faktör Analizi Sonuçları

Tablo 4. Tükenmişlik Düzeyi Faktör Analizi Sonuçları

\begin{tabular}{|c|c|c|c|c|c|c|c|}
\hline Faktör & $\begin{array}{l}\text { Faktör } \\
\text { Maddeleri } \\
\end{array}$ & $\begin{array}{l}\text { Faktör } \\
\text { Yükü }\end{array}$ & $\begin{array}{l}\text { Faktör } \\
\text { Açıklayıcılığı }\end{array}$ & Faktör & $\begin{array}{l}\text { Faktör } \\
\text { Maddeleri }\end{array}$ & Faktör Yükü & $\begin{array}{l}\text { Faktör } \\
\text { Açıklayıcılığı }\end{array}$ \\
\hline \multirow[t]{7}{*}{ İşlemsel Adalet } & İA1 & 0,595 & $\% 66,6$ & Duygusal & DT1 & 0,445 & $\% 50,6$ \\
\hline & IA2 & 0,664 & & Tükenmenme & DT4 & 0,668 & \\
\hline & IA3 & 0,686 & & & DT7 & 0,745 & \\
\hline & IA4 & 0,722 & & & DT10 & 0,647 & \\
\hline & IA5 & 0,763 & & & DT13 & 0,739 & \\
\hline & İA6 & 0,501 & & & DT16 & 0,585 & \\
\hline & IA7 & 0,609 & & & DT20 & 0,701 & \\
\hline \multirow[t]{4}{*}{ Dağıtımsal Adalet } & BA1 & 0,751 & & & DT22 & 0,592 & \\
\hline & BA2 & 0,695 & & Duyarsızlaşma & D3 & 0,650 & \\
\hline & BA3 & 0,778 & & & D6 & 0,602 & \\
\hline & BA4 & 0,730 & & & D9 & 0,592 & \\
\hline \multirow[t]{9}{*}{ Etkileşimsel Adalet } & EA1 & 0,836 & & & D12 & 0,638 & \\
\hline & EA2 & 0,820 & & & $\mathrm{D} 15$ & 0,464 & \\
\hline & EA3 & 0,845 & & $\overline{\text { Kişisel Başarıda }}$ & KB2 & 0,661 & \\
\hline & EA5 & 0,794 & & Azalma Hissi & KB5 & 0,724 & \\
\hline & EA6 & 0,790 & & & KB11 & 0,586 & \\
\hline & EA7 & 0,812 & & & KB14 & 0,418 & \\
\hline & EA8 & 0,761 & & & KB17 & 0,559 & \\
\hline & EA9 & 0,821 & & & KB19 & 0,499 & \\
\hline & & & & & KB21 & 0,669 & \\
\hline Toplam & 19 ifade & & $\% 66,6$ & Toplam & 20 ifade & & $\% 50,6$ \\
\hline
\end{tabular}

Çalışan Sessizliği Ölçeği alt ifadeden ve tek boyuttan oluşmaktadır. Yapılan analiz sonucunda KMO değeri 0,856 ve $p=0,000$ çıktğından faktör analizine uygun olduğu değerlendirilmiş ve yapılan faktör analizi sonuçları Tablo 5'te sunulmuştur.

Tablo 5. Çalışan Sessizliği Faktör Analizi Sonuçları

\begin{tabular}{|l|l|c|l|}
\hline Faktör & Faktör Maddeleri & Faktör Yükü & Faktör Açıklayıcılığı \\
\hline Çalışan Sessizliği & ÖS1 & 0,816 & \% 75,6 \\
& ÖS2 & 0,866 & \\
& ÖS3 & 0,885 & \\
& ÖS4 & 0,901 & \\
& ÖS5 & 0,893 & \\
\hline ÖS6 & 0,855 & $\% \mathbf{7 5 , 6}$ \\
\hline
\end{tabular}

Elde edilen verilerden araştrmada kullanılan ölçeklerin güvenirliklerinin ve geçerliliklerinin yüksek olduğu belirlenmiştir.

Örgüt çalışanlarının örgütsel adaletin alt boyutlarına yönelik algılarını belirlemek üzere yapılan analiz sonuçları Tablo 6 'da verilmiştir. Buna göre, işlemsel adalete ilişkin algılarının ( $\dot{X}=3,39)$, dağıtımsal adalete ilişkin algılarının $(\dot{X}=3,36)$ ve etkileşimsel adalete ilişkin algılarının $(\dot{X}=3,39)$ olumlu yönde olduğu belirlenmiştir.

Çalışan sessizliğini belirlemek üzere yapılan analiz sonucunda sessizlik tutumlarının $(\dot{X}=3,79)$ olduğu, çalışanların örgütsel faaliyetler ile ilgili konularda düşüncelerini ifade ettikleri ve katılım sağlamaya çalıştıkları ifade edilebilir. 
Tablo 6. Çalışanların Örgütsel Adalet Algısı ( $n=209)$

\begin{tabular}{|l|c|c|c|}
\hline Boyutlar & Ortalama & Standart Sapma & ifade Sayısı \\
\hline İşlemsel Adalet & 3,39 & 0,739 & 7 \\
\hline Dağıtımsal Adalet & 3,36 & 0,972 & 8 \\
\hline Etkileşimsel Adalet & 3,39 & 1,073 & 6 \\
\hline Çalışan Sessizliği & 3,79 & 0,905 & 8 \\
\hline Duygusal Tükenme & 2,52 & 0,817 & 5 \\
\hline Duyarsızlaşma & 2,35 & 0,774 & 7 \\
\hline Kişisel Başarıda Azalma Hissi & 4,76 & 0,422 & \\
\hline
\end{tabular}

Tablo 7. Tükenmişlik Düzeyleri

\begin{tabular}{|l|l|l|c|}
\hline & DUYGUSAL TÜKENME & DUYARSIZLAŞMA & $\begin{array}{c}\text { KişiSEL BAŞARIDA AZALMA } \\
\text { Hissi }\end{array}$ \\
\hline Yüksek & 3 ve üstü & 2,6 ve üstü & $0-3,8$ \\
\hline Orta & $1,8-2,9$ & $1,4-2,5$ & $3,9-4,7$ \\
\hline Düşük & $0-1,7$ & $0-1,3$ & 4,7 ve üstü \\
\hline
\end{tabular}

Kaynak: Budak ve Sürgevil (2005: 92).

"Tükenmişlik ile ilgili olarak düşük, orta ve yüksek düzeyde tükenmişlikten söz edilebilmektedir. Duygusal tükenme ve duyarsızlaşma alt ölçeklerinden alınan yüksek puan ile kişisel başarı boyutundan alınan düşük puan, yüksek tükenmişlik düzeyini ifade eder. Tersi şekilde; duygusal tükenme ve duyarsızlaşma alt ölçeklerinden alınan düşük puan ile kişisel başarı boyutundan alınan yüksek puan, düşük tükenmişlik düzeyini ifade eder. Tükenmişliğin orta düzeyi ise, her üç ölçekteki orta düzeyi belirtmektedir." (Budak ve Sürgevil, 2005: 92).

Çalışanların tükenmişlik alt boyutlarının düzeylerini belirlemeye yönelik yapılan analiz sonucunda, çalışanların duygusal tükenme düzeylerinin $(\dot{X}=2,52)$ olduğu Tablo 7'ye göre çalışanların tükenmişliklerinin orta düzeyde olduğu belirlenmiştir. Duyarsızlaşma alt boyutunun algı düzeyinin $(\dot{X}=2,35)$ olduğu ve çalışanların duyarsızlaşma düzeylerinin orta düzeyde olduğu belirlenmiştir. Kişisel başarıda azalma düzeyinin ise $(\dot{X}=4,76)$ ile düşük seviyede olduğu ifade edilebilir.

\section{Bulgular}

Çalışmada kullanılan değişkenlerin birbiri ile aralarındaki ilişkileri belirlemek üzere pearson korelasyon analizi yapılmıştır. Tablo 8'de yer alan değerler incelendiğinde, örgütsel adalet duygusunun alt boyutlarının her birinin tükenmişlik alt boyutlarından duygusal tükenme, duyarsızlaşma ve kişisel başarıda azalma boyutuyla ile negatif yönlü bir ilişkisi olduğu söylenebilir. Örgütsel adalet alt boyutları ile çalışan sessizliği arasında negatif yönlü, orta düzeyde ve anlamlı bir ilişki olduğu ifade edilebilir. Tükenmişlik alt boyutlarından duygusal tükenme, duyarsızlaşma ve kişisel başarıda azalma hissi ile çalışan sessizliği arasında pozitif yönlü bir ilişki olduğu ifade edilebilir.

Çalışanların örgütsel adalet algılarının alt boyutları ile tükenmişlik düzeylerinin alt boyutları, örgütsel adalet algılarının alt boyutları ile çalışan sessizliği tutumu ve tükenmişlik düzeylerinin alt boyutları ile çalışan sessizliği tutumu arasındaki etkilerin belirlenmesi amacıyla regresyon analizleri yapılmıştır. Yapılan regresyon analizlerinde otokorelasyon olmadığını gösteren Durbin-Watson değerlerinin 2 ve altında olduğu, çoklu doğrusallık olmadığını gösteren VIF değerlerinin 1 civarında olduğu belirlenmiş ve regresyon analizlerinde Anova tabloları incelenerek modellerin bir bütün olarak anlamlı oldukları tespit edilmiştir. 
K. Erogluer - R. C. Erselcan

Tablo 8. Korelasyon Analizi Sonuçları ( $n=209)$

\begin{tabular}{|c|c|c|c|c|c|c|c|}
\hline & $\begin{array}{l}\text { İşlemsel } \\
\text { Adalet }\end{array}$ & $\begin{array}{l}\text { Dağıtımsal } \\
\text { Adalet }\end{array}$ & $\begin{array}{l}\text { Etkileşimsel } \\
\text { Adalet }\end{array}$ & $\begin{array}{l}\text { Çalışan } \\
\text { Sessizliği }\end{array}$ & $\begin{array}{l}\text { Duygusal } \\
\text { Tükenme }\end{array}$ & Duyarsızlaşma & $\begin{array}{l}\text { Kişisel } \\
\text { Başarıda } \\
\text { Azalma Hissi }\end{array}$ \\
\hline İşlemsel Adalet & 1 & $\begin{array}{l}0,643 * * \\
0,000\end{array}$ & $\begin{array}{l}0,608^{* *} \\
0,000\end{array}$ & $\begin{array}{c}-0,581^{* *} \\
0,000\end{array}$ & $\begin{array}{c}-0,296 * * \\
0,000\end{array}$ & $\begin{array}{c}-0,153^{*} \\
0,027\end{array}$ & $\begin{array}{c}-0,567^{* *} \\
0,000\end{array}$ \\
\hline $\begin{array}{l}\text { Dağıtımsal } \\
\text { Adalet }\end{array}$ & $\begin{array}{r}0,643 * * \\
0,000 \\
\end{array}$ & 1 & $\begin{array}{l}0,540 * * \\
0,000\end{array}$ & $\begin{array}{c}-0,502 * * \\
0,000 \\
\end{array}$ & $\begin{array}{c}-0,180 * * \\
0,009 \\
\end{array}$ & $\begin{array}{r}-0,040 \\
0,566 \\
\end{array}$ & $\begin{array}{c}-0,378^{* *} \\
0,000 \\
\end{array}$ \\
\hline $\begin{array}{l}\text { Etkileşimsel } \\
\text { Adalet }\end{array}$ & $\begin{array}{r}0,608^{* *} \\
0,000 \\
\end{array}$ & $\begin{array}{l}0,540 * * \\
0,000\end{array}$ & 1 & $\begin{array}{c}-0,616^{* *} \\
0,000\end{array}$ & $\begin{array}{c}-0,337^{* *} \\
0,000\end{array}$ & $\begin{array}{c}-0,272^{* *} \\
0,000\end{array}$ & $\begin{array}{c}-0,471^{* *} \\
0,000\end{array}$ \\
\hline $\begin{array}{l}\text { Çalışan } \\
\text { Sessizliği }\end{array}$ & $\begin{array}{r}-0,581^{* *} \\
0,000\end{array}$ & $\begin{array}{l}-0,502^{* *} \\
0,000\end{array}$ & $\begin{array}{l}-0,616^{* *} \\
0,000\end{array}$ & 1 & $\begin{array}{l}0,116^{*} \\
0,094\end{array}$ & $\begin{array}{l}0,191^{* *} \\
0,006\end{array}$ & $\begin{array}{l}0,656^{* *} \\
0,000\end{array}$ \\
\hline $\begin{array}{l}\text { Duygusal } \\
\text { Tükenme }\end{array}$ & $\begin{array}{r}-0,296 * * \\
0,000 \\
\end{array}$ & $\begin{array}{l}-0,180^{* *} \\
0,009\end{array}$ & $\begin{array}{l}-0,337^{* *} \\
0,000\end{array}$ & $\begin{array}{c}0,116^{*} \\
0,094\end{array}$ & 1 & $\begin{array}{l}0,685^{* *} \\
0,000\end{array}$ & $\begin{array}{l}0,141 * \\
0,041\end{array}$ \\
\hline Duyarsızlaşma & $\begin{array}{c}-0,153^{*} \\
0,027\end{array}$ & $\begin{array}{r}-0,040 \\
0,566 \\
\end{array}$ & $\begin{array}{l}-0,272^{* *} \\
0,000\end{array}$ & $\begin{array}{l}0,191^{* *} \\
0,006\end{array}$ & $\begin{array}{l}0,685^{* *} \\
0,000\end{array}$ & 1 & $\begin{array}{c}0,171 * \\
0,014\end{array}$ \\
\hline $\begin{array}{l}\text { Kişisel } \\
\text { Başarıda } \\
\text { Azalma Hissi }\end{array}$ & $\begin{array}{l}-0,567^{* *} \\
0,000\end{array}$ & $\begin{array}{c}-0,378^{* *} \\
0,000\end{array}$ & $\begin{array}{c}-0,471^{* *} \\
0,000\end{array}$ & $\begin{array}{l}0,656^{* *} \\
0,000\end{array}$ & $\begin{array}{l}0,141^{*} \\
0,041\end{array}$ & $\begin{array}{l}0,171^{*} \\
0,014\end{array}$ & 1 \\
\hline
\end{tabular}

$p=0,05^{*}, p=0,01^{* *}$

Çalışmanın birinci hipotezi olan "H1: Çalışanların dağıtımsal adalet algıları duygusal tükenme düzeylerini olumsuz etkiler." hipotezine ilişkin sonuçlar Tablo 9' da verilmiştir. Buna göre çalışanların duygusal tükenme algılarının yalnızca \%3,2'lik kısmının dağıtımsal adalet algısı tarafindan açıklandığı, modelin bir bütün olarak anlamlı olduğu, dağıtımsal adalet ile duygusal tükenme arasında olumsuz yönlü ve zayıf bir ilişki olduğu belirlenmiştir. Dağıtımsal adalet algısındaki bir birimlik artı̧ duygusal tükenmeyi 0,139 birim azaltmaktadır. Örgütün çalışanları için belirlediği ödül ve diğer maddi katkıların dağıtımına, bölüşümüne ilişkin olumlu algılarının duygusal tükenmeleri üzerinde olumsuz etki yaratacağı veya çalışanların duygusal tükenme düzeylerini azaltacağı ifade edilebilir. Dolayısıyla birinci hipotez $\% 5$ anlamlılık düzeyinde $\left(p=0,009, R^{2}=-0,180\right)$ kabul edilmiştir.

Tablo 9. Regresyon Analizi Sonuçları

\begin{tabular}{|c|c|c|c|c|c|c|c|c|c|c|c|}
\hline Hipotez & $\begin{array}{l}\text { Bağımsız } \\
\text { Değişken }\end{array}$ & $\begin{array}{l}\text { Bağımlı } \\
\text { Değişken }\end{array}$ & $\mathbf{R}$ & $\mathbf{R}^{2}$ & $\beta$ & $\begin{array}{c}\text { Stand. } \\
\beta\end{array}$ & $\mathbf{t}$ & $\mathbf{F}$ & p & $\begin{array}{l}\text { Dubrin- } \\
\text { Watson }\end{array}$ & Sonuç \\
\hline $\mathrm{H} 1$ & \multirow{3}{*}{$\begin{array}{l}\text { Dağıtımsal } \\
\text { Adalet }\end{array}$} & $\begin{array}{l}\text { Duygusal } \\
\text { Tükenme }\end{array}$ & 0,180 & 0,032 & $-0,139$ & $-0,180$ & $-2,626$ & 6,897 & 0,009 & 1,826 & KABUL \\
\hline $\mathrm{H} 2$ & & Duyarsızlaşma & 0,040 & 0,002 & $-0,032$ & $-0,040$ & $-0,575$ & 0,331 & 0,566 & 1,566 & RET \\
\hline H3 & & $\begin{array}{l}\text { Kişisel Başarıda } \\
\text { Azalma Hissi }\end{array}$ & 0,378 & 0,143 & $-0,259$ & $-0,378$ & $-5,875$ & 43,514 & 0,000 & 1,776 & KABUL \\
\hline $\mathrm{H} 4$ & \multirow{3}{*}{ İşlemsel Adalet } & $\begin{array}{l}\text { Duygusal } \\
\text { Tükenme }\end{array}$ & 0,296 & 0,088 & $-0,302$ & $-0,296$ & $-4,460$ & 19,892 & 0,000 & 2,064 & KABUL \\
\hline H5 & & Duyarsızlaşma & 0,153 & 0,023 & $-0,160$ & $-0,153$ & $-2,227$ & 4,959 & 0,027 & 1,752 & KABUL \\
\hline H6 & & $\begin{array}{l}\text { Kişisel Başarıda } \\
\text { Azalma Hissi }\end{array}$ & 0,567 & 0,321 & $-0,511$ & $-0,567$ & $-9,895$ & 97,903 & 0,000 & 1,975 & KABUL \\
\hline $\mathrm{H} 7$ & \multirow{3}{*}{$\begin{array}{l}\text { Etkileşimsel } \\
\text { Adalet }\end{array}$} & $\begin{array}{l}\text { Duygusal } \\
\text { Tükenme }\end{array}$ & 0,337 & 0,113 & $-0,262$ & $-0,337$ & $-5,144$ & 26,465 & 0,000 & 2,037 & KABUL \\
\hline $\mathrm{H} 8$ & & Duyarsızlaşma & 0,272 & 0,074 & $-0,217$ & $-0,272$ & $-4,060$ & 16,486 & 0,000 & 1,888 & KABUL \\
\hline H9 & & $\begin{array}{l}\text { Kişisel Başarıda } \\
\text { Azalma Hissi }\end{array}$ & 0,471 & 0,222 & $-0,324$ & $-0,471$ & $-7,688$ & 59,102 & 0,000 & 1,898 & KABUL \\
\hline $\mathrm{H} 10$ & $\begin{array}{l}\text { Dağıtımsal } \\
\text { Adalet }\end{array}$ & \multirow{3}{*}{ Çalışan Sessizliği } & 0,502 & 0,252 & $-0,468$ & $-0,502$ & $-8,351$ & 69,739 & 0,000 & 1,610 & KABUL \\
\hline $\mathrm{H} 11$ & İşlemsel Adalet & & 0,581 & 0,337 & $-0,711$ & $-0,581$ & $-10,26$ & 105,224 & 0,000 & 1,918 & KABUL \\
\hline $\mathrm{H} 12$ & $\begin{array}{l}\text { Etkileşimsel } \\
\text { Adalet }\end{array}$ & & 0,616 & 0,379 & $-0,576$ & $-0,616$ & $-11,25$ & 126,580 & 0,000 & 1,696 & KABUL \\
\hline $\mathrm{H} 13$ & $\begin{array}{l}\text { Duygusal } \\
\text { Tükenme }\end{array}$ & \multirow{3}{*}{ Çalışan Sessizliği } & 0,116 & 0,013 & 0,139 & 0,116 & 1,683 & 2,832 & 0,094 & 1,652 & RET \\
\hline $\mathrm{H} 14$ & Duyarsızlaşma & & 0,191 & 0,036 & 0,223 & 0,191 & 2,795 & 7,812 & 0,006 & 1,729 & KABUL \\
\hline $\mathrm{H} 15$ & $\begin{array}{l}\text { Kişisel Başarıda } \\
\text { Azalma Hissi }\end{array}$ & & 0,656 & 0,431 & 0,892 & 0,656 & 12,514 & 156,594 & 0,000 & 1,739 & KABUL \\
\hline
\end{tabular}


İkinci hipotez olan "H2: Çalışanların dağıtımsal adalet algıları duyarsızlaşma düzeylerini olumsuz etkiler." hipotezi yapılan analiz sonucunda $\left(p=0,566, R^{2}=0,002\right)$ kabul edilmemiştir. Dağıtımsal adalet algısının duyarsızlaşma üzerinde bir etkisinin olmadığı belirlenmiştir.

Dağıtımsal adalet algısı ile kişisel başarıda azalma hissi arasındaki ilişkiyi belirlemeye yönelik oluşturulan üçüncü hipotez "H3: Çalışanların dağıttmsal adalet algıları kişisel başarıda azalma hislerini olumsuz yönde etkiler." hipotezi \%5 anlamlılık düzeyinde $\left(p=0,000 ; R^{2}=0,143\right)$ kabul edilmiştir. Dağıtımsal adalet algısıyla kişisel başarıda azalma hissi arasında olumsuz yönlü bir ilişki olduğu Tablo 8'de yer alan verilerden anlaşılmakta ve kişisel başarıda azalma hissindeki değişimin \%14,3'lük kısmının dağıtımsal adalet algısı tarafindan açıklandığı ifade edilebilir. Dağıtımsal adalet algısındaki bir birimlik artış kişisel başarıda azalma hissini 0,259 birim azaltmaktadır. Oluşturulan üçüncü hipotez $\% 5$ anlamlılık düzeyinde $(p=0,000$; $\left.\mathrm{R}^{2}=0,143\right)$ kabul edilmiştir.

İşlemsel adalet algısının duygusal tükenme üzerindeki etkisini belirlemeye yönelik oluşturulan dördüncü hipotez "H4: Çalışanların işlemsel adalet algıları duygusal tükenme düzeylerini olumsuz etkiler." hipotezi \%5 anlamlılık düzeyinde $\left(p=0,000 ; R^{2}=0,088\right)$ kabul edilmiştir. Tablo $8^{\prime}$ de yer alan verilerden işlemsel adalet ile duygusal tükenme arasında olumsuz yönlü ilişki olduğu ifade edilebilir. Iş̧lemsel adalet algısındaki bir birimlik artş̧ duygusal tükenme düzeyini 0,302 birim azaltmaktadır. İşlemsel adalete ilişkin olumlu algının duygusal tükenme üzerinde olumsuz yönde etki edeceği, duygusal tükenmeyi azaltacağı ifade edilebilir.

İşlemsel adalet algısının duyarsızlaşma düzeyi üzerindeki etkisini belirlemeye yönelik oluşturulan beşinci hipotez "H5: Çalışanların işlemsel adalet algıları duyarsızlaşma düzeylerini olumsuz etkiler." hipotezi $\% 5$ anlamlılık düzeyinde $\left(p=0,027 ; R^{2}=0,023\right)$ kabul edilmiştir. Tablo $8^{\prime}$ deki verilerden işlemsel adalet algısı ile duyarsızlaşma arasında olumsuz yönlü ilişki olduğu belirlenmiştir. İşlemsel adalet algısındaki bir birimlik artı̧̧ duyarsızlaşma düzeyini 0,160 birim azaltmaktadır. İşlemsel adalet algısının olumlu yönde artması çalışanların duyarsızlaşma düzeyini azaltacağı ifade edilebilir.

İşlemsel adalet ile kişisel başarıda azalma arasındaki ilişkiyi belirlemeye yönelik oluşturulan altıncı hipotez olan "H6: Çalışanların işlemsel adalet algıları kişisel başarıda azalma hissini olumsuz etkiler." hipotezi $\% 5$ anlamlılık düzeyinde $\left(p=0,000 ; R^{2}=0,321\right)$ kabul edilmiştir. Tablo 8 'de yer alan analiz sonuçlarına göre işlemsel adalet ile kişisel başarıda azalma hissi arasında olumsuz yönlü ve orta düzeyde bir ilişki olduğu ifade edilebilir. Tablo 9'a göre işlemsel adalet algısı kişisel başarıda azalma hissindeki değişimin \%32,1'lik kısmını açıkladığı, \%67,9'luk kısmının ise kontrol edilemeyen diğer değişkenler tarafindan açıklandığı ifade edilebilir. Buna göre işlemsel adalet algısındaki bir birimlik artşs kişisel başarıda azalma hissini 0,511 birim azaltmaktadır. Çalışanların işlemsel adalet algılarının olumlu yönde artması kişisel başarıda azalma hissini azaltacağı ifade edilebilir.

Yedinci hipotez olan "H7: Çalışanların etkileşimsel adalet algıları duygusal tükenme düzeylerini olumsuz etkiler." hipotezi $\% 5$ anlamlılık düzeyinde $\left(p=0,000 ; R^{2}=0,113\right)$ kabul edilmiştir. Tablo 8 'de yer alan verilere göre etkileşimsel adalet algısı ile duygusal tükenme düzeyi arasında olumsuz yönlü bir ilişki olduğu, Tablo 9'a göre çalışanların duygusal tükenme düzeyleri üzerindeki değişimin \%11,3'lük kısmının etkileşimsel adaletten kaynakladığı ve çalışanların etkileşimsel adalet algılarındaki bir birimlik artş̧ın duygusal tükenme düzeylerini 0,262 birim azalttı̆ı ifade edilebilir.

Etkileşimsel adalet ile duyarsızlaşma düzeyi arasındaki ilişkiyi belirlemeye yönelik oluşturulan sekizinci hipotez "H8: Çalışanların etkileşimsel adalet algıları duyarsızlaşma düzeylerini olumsuz etkiler." hipotezi \%5 anlamlılık düzeyinde $\left(p=0,000 ; R^{2}=0,074\right)$ kabul edilmiştir. Tablo 8 'de yer alan analiz sonuçlarına göre etkileşimsel adalet ile duyarsızlaşma arasında olumsuz yönlü bir ilişki olduğu ve Tablo 9'a göre duyarsızlaşma düzeyindeki değişimin \%7,4'lük kısmının etkileşimsel adalet algısından kaynaklandığı belirlenmiştir.

Etkileşimsel adalet ile kişisel başarıda azalma hissi arasındaki ilişkiyi belirlemeye yönelik oluşturulan dokuzuncu hipotez olan "H9: Çalışanların etkileşimsel adalet algıları kişisel başarıda azalma hissini olumsuz etkiler." hipotezi \% 5 anlamlılık düzeyinde $\left(p=0,000 ; R^{2}=0,222\right)$ kabul edilmiştir. Tablo 8 'de yer alan analiz sonuçlarına göre etkileşimsel adalet algısı ile kişisel başarıda azalma hissi arasında olumsuz yönlü bir ilişki 
olduğu ve Tablo 9'daki verilere göre kişisel başarıdaki azalma hissindeki değişimin \% 22,2'lik kısmının etkileşimsel adalet algısından kaynaklandığı belirlenmiştir. Çalışanların etkileşimsel adalet algılarındaki bir birimlik artışın kişisel başarıda azalma hislerini 0,324 birim azalttğı ifade edilebilir.

Onuncu hipotez olan "H10: Çalışanların dağıtımsal adalet algıları çalışan sessizliğini olumsuz yönde etkiler." hipotezine yönelik dağıtımsal adalet algısı ile çalışan sessizliği arasındaki ilişkinin olumsuz yönlü ve orta düzeyde olduğuna ilişkin veriler Tablo 8'de sunulmuştur. Tablo 9'a göre çalışan sessizliğindeki değişimin \%25,2'sinin dağıtımsal adaletten kaynaklandığı, çalışanların dağıtımsal adalet algılarındaki bir birimlik değişimin çalışan sessizliğini 0,468 birim azalttğı ifade edilebilir. Hipotez $\% 5$ anlamlılık düzeyinde $(p=0,000$; $\left.\mathrm{R}^{2}=0,252\right)$ kabul edilmiştir.

İşlemsel adalet algısı ile çalışan sessizliği arasındaki ilişkiyi belirlemek üzere oluşturulan on birinci hipotez "H11: Çalışanların işlemsel adalet algıları çalışan sessizliğini olumsuz yönde etkiler." hipotezi \%5 anlamlılık düzeyinde $\left(p=0,000 ; R^{2}=0,337\right)$ kabul edilmiştir. Tablo 8 'deki verilere göre işlemsel adalet algısı ile çalışan sessizliği arasındaki ilişkinin olumsuz yönde ve orta düzeyde olduğu ifade edilebilir. Tablo 9'a göre çalışan sessizliğindeki değişimin \% 33,7'si işlemsel adalet algısından kaynaklandığı, çalışanların işlemsel adalet algıları olumlu yönde arttkça çalışan sessizliğinin azalacağı ifade edilebilir. Çalışanların olumlu işlemsel adalete ilişkin algıları örgütsel süreçlerle ilgili olarak çalışanların olumsuz duyguları ve düşüncelerini açıkça dile getirebilecekleri ifade edilebilir.

Çalışanların etkileşimsel adalet algılarının çalışan sessizliği ile ilişkisini belirlemek üzere oluşturulan on ikinci hipotez "H12: Çalışanların etkileşimsel adalet algıları çalışan sessizliğini olumsuz yönde etkiler." hipotezi $\% 5$ anlamlılık düzeyinde $\left(p=0,000 ; R^{2}=0,379\right)$ kabul edilmiştir. Tablo 8'e göre etkileşimsel adalet ile çalışan sessizliği arasında olumsuz yönlü bir ilişki olduğu ve Tablo 9'a göre çalışan sessizliğindeki değişimin \%37,9'unun etkileşimsel adaletten kaynaklandığı ve etkileşimsel adalet algısındaki bir birimlik değişimin çalışan sessizliğini 0,576 birim azalttı̆ı belirlenmiştir. Üstleri ve amirleriyle olumlu yönde ilişkileri olan, süreçler hakkında bilgilendirilen çalışanların olumlu örgütsel adalet algıları dolayı sessiz kalmayabilecekleri ifade edilebilir.

On üçüncü hipotez olan "H13: Çalışanların duygusal tükenme düzeyi çalışan sessizliğini olumlu yönde etkiler." hipotezi \%5 anlamlılık düzeyinde $\left(p=0,094 ; R^{2}=0,013\right)$ kabul edilmemiştir. Duygusal tükenmenin çalışan sessizliği üzerinde bir etkisinin olmadığı belirlenmiştir.

Çalışanların duyarsılaşma düzeyleri ile çalışan sessizliği tutumları arasındaki ilişkiyi incelemeye yönelik oluşturulan on dördüncü hipotez olan "H14: Çalışanların duyarsızlaşma düzeyleri çalışan sessizliğini olumlu yönde etkiler." hipotezi "\% 5 anlamlılık düzeyinde $\left(p=0,006 ; R^{2}=0,036\right)$ kabul edilmiştir. Tablo 8'deki verilere göre duyarsızlaşma düzeyi ile çalışan sessizliği tutumu arasında olumlu yönlü ancak zayıf bir ilişki olduğu bulunmuştur. Çalışanların duyarsızlaşma düzeyleri arttıkça sessizlik tutumlarının da artacağı ifade edilebilir.

On beşinci hipotez olan "H15: Çalışanların kişisel başarıda azalma hissi çalışan sessizliği tutumlarını olumlu yönde etkiler." hipotezi $\% 5$ anlamlılık düzeyinde $\left(p=0,000 ; R^{2}=0,431\right)$ kabul edilmiştir. Çalışan sessizliğindeki değişimin \%43,1'lik kısmının kişisel başarıda azalma hissinden kaynaklandığı, kişisel başarıda azalma hissindeki bir birimlik artı̧ın çalışan sessizliğini 0,892 birim arttırdığı belirlenmiştir. Çalışanların kişisel başarıda azalma hissi arttıkça çalışan sessizliğinin de buna paralel olarak artacağı ifade edilebilir.

\section{Sonuç}

Örgütlerde adalet algısının çalışanların moral ve motivasyonları üzerinde çok önem etkisi vardır. Aynı bölümde işini iyi yapan ile sadece işini yapan arasındaki ayrım çalışanlar tarafindan net bir şekilde yapılabilirken bu değerlendirmenin yönetim tarafindan farklı yapılması veya çalışanlar tarafindan farklı algılanması örgütün adaleti ile ilgili çalışanların zihninde soru işareti yaratabilir. Örgüt insan kaynağını nasıl ki en iyilerden oluşturmaya çalışıyorsa, işe alınan çalışanlar için de örgüt imkanları dahilinde en iyisininin yapılması bir gereklilik olarak ortaya çıkmaktadır.

Çalışanlar tarafindan algılanan örgütsel adalet veya adaletsizlik olumlu veya olumsuz pek çok davranış ve tutumun ortaya çıkmasına neden olacaktır. Bu olumsuz duygulardan biri de tükenmişliktir. Tükenmişlik 
günümüzde insanlarla yoğun ilişkili tüm meslek gruplarında en alt kademeden en üst kademeye kadar her çalışanda rastlanabilen bir duygudur. Bu duygunun tetikleyici unsurlarından birisi de çalışanların adalet algısı olduğu ifade edilebilir (Liljegren ve Ekberg, 2009: 47). Zira insan topluluklarında adalet algısı insanları bir arada tutan birleştirici bir unsurdur.

Örgütlerde beklentilerine karşlık bulamayan çalışanlar tatminsizlik başta olmak üzere pek çok olumsuz duygu yaşayabilir. Tükenmişlik de bu duygulardan birisidir. Çalışanların tükenmişliği, çevresinde olan bitene tepkisiz kalmayı ve daha da önemlisi sessizliğe neden olabilir. Örgütlerde çalışanların sessizliği başlangıçta yönetim tarafindan olumlu algılansa da aslında örgütlerin fikir ve proje üretimini olumsuz yönde etkileyen, rekabet avantajının kaybedildiği ciddi bir problemdir. Sessizlik çalışanların çeşitli kaygılardan ötürü yönetime önemli mesajlar verdikleri bir tutumdur. Günümüz şartlarında çalışan sessizliğinin örgütler için önemli bir problem olduğu göz önünde bulundurularak çalışanların kendilerini her durumda ifade edebilecekleri olumlu bir örgüt ikliminin yaratılması çok önemlidir.

Çalışmada örgütsel adalet ile tükenmişlik arasındaki ilişkiyi belirlemeye yönelik olarak her iki konunun alt boyutlarının birbiri ile olan ilişkisinin belirlenmesi; ardından örgütsel adalet alt boyutları ile çalışan sessizliği arasındaki ilişkinin belirlenmesi; daha sonra tükenmişlik alt boyutları ile çalışan sessizliği ilişkisinin belirlenmesine çalışılmıştır. Bu amaçla korelasyon analizi ile birlikte bağımsız değişkenlerin bağımlı değişkenler üzerindeki etkilerini belirlemek amacıyla hipotezler oluşturulmuş ve aralarındaki ilişkiler incelenmiştir.

Yapılan korelasyon analizi sonucunda örgütsel adalet alt boyutlarının tükenmişlik alt boyutlarından duygusal tükenme, duyarsızlaşma ve kişisel başarıda azalma hissi alt boyutları ile arasında negatif yönlü ve zayıf ilişki olduğu sonucuna ulaşılmıştır. Duygusal tükenme, duyarsızlaşma ve kişisel başarıda azalma hissi ile çalışan sessizliği arasında pozitif yönlü bir ilişki bulunmuştur. Örgütsel adalet alt boyutları olan dağıtımsal, işlemsel ve etkileşimsel adalet alt boyutlarının çalışan sessizliği ile negatif yönlü ilişkisi olduğu sunucuna ulaşılmıştır.

Oluşturulan hipotezler için yapılan regresyon analizleri sonucunda örgütsel adalet konusunun alt boyutları olan dağıtımsal adalet, işlemsel adalet ve etkileşimsel adaletin her birinin tükenmişlik alt boyutlarının her biri ile olan ilişkileri incelenmiştir. Buna göre birinci hipotez olarak çalışanların dağıtımsal adalet algılarının duygusal tükenme düzeylerini olumsuz yönde etkilediği kabul edilmiştir. Çalışanların dağıtımsal adalet algıları olumlu yönde arttkça duygusal tükenme düzeylerinin azalacağı ifade edilebilir. Benzer sonuca Hur vd. (2014:201), Köse (2014: 68), Uluköy (2014: 213), Frenkel vd., (2012: 121), Lambert vd. (2010: 7) ve Yeniçeri vd. (2009: 83) yaptıkları çalışmada ulaşmışlardır. İinci hipotez olan çalışanların dağıtımsal adalet algılarının duyarsızlaşma algılarını olumsuz yönde etkilediği hipotezi beklenenin aksine kabul edilmemiştir. Çalışanların olumlu yöndeki dağıtımsal adalet algılarının Köse'nin (2014: 68) yaptığı çalışma sonucuna benzer şekilde, duyarsızlaşma algılarını azaltması beklenir. Ancak çalışmada dağıtımsal adalete ilişkin olumlu yöndeki algılarının duyarsızlaşmaları üzerinde kişilik özelliklerinden veya örgüt ikliminden ötürü olumsuz yönde etkisi olmayabileceği ifade edilebilir. Dağıtımsal adalet algısı ile kişisel başarıda azalma hissi arasındaki ilişkiyi belirlemeye yönelik oluşturulan üçüncü hipotez kabul edilmiş, çalışanların dağıtımsal adalet algılarının kişisel başarıda azalma hislerini olumsuz yönde etkilediği sonucuna ulaşılmıştır. Benzer sonuca Yıldırım vd. (2012: 330) yaptıkları çalışmada ulaşmışlardır. Adalet algısının yüksek olduğu örgütlerdeki olumlu kültür ve örgüt ikliminin çalışanların kişisel başarıda azalma hislerini azaltması beklenir.

Örgütlerdeki süreçlerle ilgili olan işlemsel adalet algısının tükenmişlik boyutları üzerindeki etkisini belirlemeye yönelik oluşturulan hipotezlerden dördüncü hipotez olan işlemsel adalet algısının duygusal tükenmeyi olumsuz yönde etkilediği hipotezi kabul edilmiştir. Benzer sonuca Liljegren ve Ekberg (2009: 47) ve Lambert vd. (2010: 7) ulaşmışlardır. Aghaei, Moshiri ve Shahrbanian (2012: 2438) çalışmalarında örgütsel adalet ile tükenmişlik arasında olumsuz yönde bir ilişki olduğunu, işlemsel adaletin tükenmişlik ile en çok olumsuz ilişkisi gösteren alt boyuttu olduğunu belirlemişlerdir. Dağıtımsal adaletin tükenmişliğin belirleyicisi olduğuna işaret etmişlerdir. 
Beşinci hipotez olan işlemsel adalet algısının duyarsızlaşmayı olumsuz yönde etkilediği ve altıncı hipotez olan işlemsel adalet algısının kişisel başarıda azalma hissini olumsuz yönde etkilediği hipotezleri kabul edilmiştir. Benzer sonuca Meydan vd. (2011: 175) yaptıkları çalışmada ulaşmışlardır. İşlemsel adalet algısı olumlu olan çalışanların duygusal tükenmelerinin azalacağı Hur vd. (2014:202) duyarsızlaşmalarının ve kişisel başarıda azalma hissinin azalacağı ifade edilebilir.

Örgütsel adalet alt boyutlarından etkileşimsel adaletin tükenmişlik boyutlarından duygusal tükenmeyi olumsuz yönde etkilediği yönünde oluşturulan yedinci hipotez kabul edilmiştir. Üst ve amirlerin çalışanlarla olan ilişkileri ne derece olumlu ve ne derece bilgilendirici, destekleyici olursa o derece çalışanların duygusal tükenmişliklerinin azalacağı ifade edilebilir. Benzer sonuç Hur vd. (2014: 202), Son vd. (2014: 12) ve Yeniçeri vd. (2009: 83)'nin çalışmalarında da yer almaktadır. Çalışanların etkileşimsel adalet algılarının duyarsızlaşmayı olumsuz yönde etkilediğine ilişkin oluşturulan sekizinci hipotez kabul edilmiştir. Yıldırım vd. (2012: 330), Son vd. (2014: 13) yaptıkları çalışmada etkileşimsel adalet ile duyarsızlaşma arasında anlamlı ilişki olduğunu belirtmişlerdir. Çalışanların etkileşimsel adalet algıları olumlu yönde arttkça duyarsızlaşma algılarının azalacağı ifade edilebilir. Çalışanların etkileşimsel adalet algılarının kişisel başarıda azalma hissini olumsuz yönde etkileyeceğine yönelik oluşturulan onuncu hipotez kabul edilmiştir. Benzer sonuca Köse (2014: 68) de yaptığı çalışmasında ulaşmıştır. Etkileşimsel adalet algısının olumlu yönde artması çalışanların kişisel başarıda azalma hissini olumsuz yönde etkileyeceği ifade edilebilir.

Örgütsel adalet boyutlarının çalışan sessizliğini etkilemesine yönelik oluşturulan hipotezlerden on, on bir ve on ikinci hipotezler kabul edilmiştir. Örgütsel adalet boyutları ile çalışan sessizliği arasında negatif yönde anlamlı ilişki olduğu ifade edilebilir. Yapılan bir çalışmada örgütsel adalet ile çalışan sessizliği arasında negative yönlü ilişki olduğu (Zahed, 2015; 752), bir diğer araştırmada işe bilgilendirici adaletinin çalışanların konuşma niyetleri üzerinde olumlu yönde etkili olduğu sonucuna ulaşılmıştır (Makens, 2016; 1). Buna göre olumlu yöndeki dağıtımsal adalet, işlemsel adalet ile etkileşimsel adalet algısının çalışan sessizliğini olumsuz yönde etkileyebileceği ifade edilebilir. Tulubaş ve Celep (2012; 280 ) çalışanların işlemsel adalet algısının çalışanların sessizliğinde etkili olduğunu belirtmişlerdir. Özçınar vd. (2015: 150) yaptıkları çalışmada örgütsel adaletin alt boyutları ile örgütsel sessizliğin alt boyutları arasında anlamlı ilişkiler olduğunu belirlemişlerdir. Huang ve Huang (2016: 838) etkileşimsel adaletin çalışan sessizliğini azaltthğı yönünde bulgulara ulaşmışlardır. Ancak Wang ve Jiang (2015: 209) etkileşimsel adalet ile çalışan sessizliği arasında olumlu yönde ilişki olduğunu belirtmişlerdir. Ünlü vd. (2015: 140) yaptıkları çalışmada örgütsel adalet boyutları ile savunmacı sessizlik boyutu arasında negatif, diğer sessizlik boyutları ile arasında pozitif ilişki olduğu sonucuna ulaşmışlardır. Nitekim örgütsel uygulamalardaki adalet algısı çalışanları olumlu yönde etkileyerek örgütün süreçlerine olan destek ve katılımlarını kuvvetlendireceği ve sessizliklerini azaltabileceği ifade edilebilir.

Tükenmişlik boyutlarının çalışan sessizliğine olan etkisini belirlemek üzere oluşturulan hipotezlerden on üçüncü hipotez "çalışanların duygusal tükenmişlik algısı çalışan sessizliğini olumlu yönde etkiler" hipotezi kabul edilmemiştir. Tahmasebi vd. (2013: 272) çalışmalarında duygusal tükenmişlik ve duyarsızlaşma ile çalışan sessizliği arasında güçlü bir ilişki bulunduğunu, çalışan sessizliği ile kişisel başarıda azalma hissi arasında ilişki olmadığını belirlemişlerdir. Çiftçi vd. (2015: 996) yaptıkları çalışmada çalışan sessizliği ile tükenmişlik arasında anlamlı bir ilişki saptayamamışlardır. Çalışamada benzer sonuca ulaşılmıştır. Duygusal tükenmişlik arttıkça çalışanların sessizliğinin artacağı beklenirken çalışma neticesinde aralarında bir ilişki bulunamamıştır. Bunda uygulama yapılan imalat sektörünün uzmanlık gücünün etkisi olduğu, çalışanların işi bizzat yapan kişiler olması nedeniyle tükenmişlik yaşasalar bile işlerine sahip çıkarak düşüncelerini ifade edebilecekleri söylenebilir. Diğer hipotezler olan duyarsızlaşma algısının ve kişisel başarıda azalma hissinin çalışan sessizliği tutumunu olumlu yönde etkilediği, çalışanların duyarsızlaşma algıları ve kişisel başarıda azalma hissi arttıķ̧a çalışan sessizliğinin artabileceği ifade edilebilir. Nitekim çalışanların tükenmişlik düzeyleri arttkça sessizlik tutumlarının artacağı beklenir (Aktaş ve Şimşek, 2015: 205; Akın ve Ulusoy, 2016: 46; Tahmasebi vd., 2013: 257).

Çalışma sonucunda elde edilen veriler değerlendirildiğinde, örgütlerin çalışanların örgütsel adalet algılarını yüksek tutmaya yönelik politikalar izlemeleri, uygulamalar yapmaları çalışanların tükenmişlik yaşamaları ve sessiz kalmaları üzerinde etkili olduğu ifade edilebilir. Özellikle uygulanan yönetsel politikalar, 
sağlıklı örgütsel iletişim, olumlu bir örgüt kültürü ve ikliminin oluşturulması çalışan sessizliğinin ve tükenmişlik düzeylerinin azalmasında çok önemli rol oynayacağı değerlendirilmektedir.

Yapılan bu çalışmada imalat sektörünün bir kolundaki çalışanlar hedef kitle olarak seçilmiştir. İmalat sektörü diğer sektörlere nazaran uzmanlık gücünün daha yüksek olduğu, çalışan ve yönetici etkileşimin üst seviyede olduğu bir sektördür. Çalışanların üretime olan doğrudan katkısı, elle tutulur gözle görülür sonuca ulaşmaları onların tükenmişlik algıları ve sessizlik tutumlarını olumsuz yönde etkilemeyebilir.

Örgütsel başarıya ulaşmada uygulanan örgütsel politikaların iç müşteriler olan çalışanlar üzerinde önemli etkileri vardır. İ̧ süreçlerine yönelik uygulamaların yanında terfi, ödül, ceza ve eğitim gibi konularda örgütün kural ve prosedürlerinin her çalışana eşit olarak uygulandığının açık ve etkin bir iletişim sistemi ile paylaşılması çalışanların örgütsel adalet algıları üzerinde olumlu etki yaratabilecektir. Bu nedenle örgüt yönetimlerinin etkin bir iletişim sistemi yanında olumlu bir örgüt iklimi de oluşturmaları gereklidir.

Tükenmişlik örgüt içinde tüm statülerdeki çalışanlar üzerinde olumsuz etkisi olan önemli konulardan birisidir. Uygulanan örgütsel politikalar, kişiler arası ilişkilerin kalitesi, kişisel gelişime yönelik faaliyetler ile örgütsel destek uygulamalarının çalışanların tükenmişlik düzeylerini azaltabileceği değerlendirilmektedir.

İşe yönelik beklentilerinin karşılanmadığını, fikir ve tekliflerinin olumsuz değerlendirildiğini düşünen çalışanlar zamanla fikir ve düşüncelerini beyan etmekten kaçınarak sessiz kalabilirler. Örgüt yönetimleri tarafindan çalışanların kendilerini ifade etmelerine yardımcı olacak tedbirleri almanın yanında, iş süreçlerine ve örgüt politikalarına yönelik eleştiri ve düşüncelerini ifade edebilecekleri çalışma ortamının oluşturulması çalışanların örgüte yapacakları katkıyı arttırabilcektir. Örgüt yöneticileri çalışanların sessiz kalmalarını engellemek için çalışanların karar verme sürecine katlabildikleri dinamik bir örgütsel adalet atmosferi yaratmalıdırlar (Zhang, Zhou ve Zhao, 2013;

Araştırmanın bir sektörün bir iş kolunda yapılmış olması, örgütlerdeki çalışanların bir kısmına ulaşılmış olması ve maliyeti bu çalışma için kısıtlardan bazılarıdır. Gelecekte yapılacak olan çalışmaların kamuda ve özel sektörün bilişim, hizmet, üretim, turizm veya sağlık gibi iş kollarında uygulanması ile farklı sonuçlar elde edilebilecektir. Örgüt kültürünün önemli bir değişken olduğu göz önüne alındığında çok uluslu büyük ölçekli işletmelerde de benzer çalışmanın yapılması ile daha farklı sonuçlara ulaşılabileceği ve aynı zamanda örgütsel sessizlik kounusu üzerinde durulmasının örgütün verimliliği üzerinde olumlu yönde katkı sağlayacağı değerlendirilmektedir.

\section{Son Notlar}

1. Bu çalışmada önerilerini ve desteğini esirgemeyen Dokuz Eylül Üniversitesi Öğretim Üyesi Doç.Dr.Olca Sürgevil Dalkılı̧̧'a teşekkür ederiz.

\section{Kaynaklar}

Adams, J. Stacy. (1965). Inequity in social exchange. In L. Berkowitz (ed.), Advances in Experimental Social Psychology, 2: 267-300. New York: Academic Press.

Aghaei, N., Moshiri, K., \& Shahrbanian, S. (2012). Relationship between organizational justice and job burnout in employees of Sport and Youth Head Office of Tehran. Advances in Applied Science Research, 3 (4), 2438-2445.

Akın, U., \& Ulusoy T. (2016). The Relationship between organizational silence and burnout among Academicians: A research on Universities in Turkey. International Journal of Higher Education, 5(2), 46-58.

Aktaş, H., \& Şimşek, E. (2015). Bireylerin örgütsel sessizlik tutumlarında iş doyumu ve duygusal tükenmişlik algılarının rolü. Uluslararası Yönetim iktisat ve işletme Dergisi, 11(24), 205-230

Altıntaş, F. Ç. (2006). Bireysel değerlerin örgütsel adalet ve sonuçları ilişkisinde yönlendirici etkisi: Akademik personel üzerinde bir analiz. İşletme Fakültesi Dergisi, 7(2), 19-40

Arı, G. S., \& Bal, E. Ç. (2008). Tükenmislik kavramı: Birey ve örgütler açısından önemi. Celal Bayar Üniversitesi i.i.B.F. Yönetim ve Ekonomi, 15(1), 131-148. 
Bagheri, G., Reihaneh, Z., \& Mojtaba, N. A. (2012). Organizational silence (basic concepts and its development factors). Ideal Type of Management, 1(1), 47-58.

Balaban, Ö., \& Konyalı, H. (2016). Kamu çalışanlarının tükenmişlik düzeyleri ile örgütsel adalet algıları arasındaki ilişkinin incelenmesi: Sakarya SGK örneği. Siyaset, Ekonomi ve Yönetim Araştirmaları Dergisi, 4(1), 189-207.

Banerjee, R., \& Banerjee S. (2013). A Study of Perceived Organizational Justice, Trust, and Organisational Citizenship Behaviour. IOSR Journal of Business and Management, 12(4):36-43.

Basım, H. N., \& Şeşen, H. (2006). örgütsel vatandaşlık davranışı ölçeği uyarlama ve karşılaştırma çalısması. Ankara Üniversitesi Siyasal Bilgiler Fakültesi Dergisi, 61(4), 83- 102.

Batool, S. (2013). Developing organizational commitment and organizational justice to amplify organizational citizenship behavior in banking sector. Pakistan Journal of Commerce and Social Sciences, 7(3), 646-655.

Bildik, B. (2009). Liderlik tarzları, örgütsel sessizlik ve örgütsel bağıılı ilişkisi. Gebze Yüksek Teknoloji Enstitüsü, Yüksek Lisans Tezi, Gebze.

Bisel, R. S., \& Arterburn, E. N. (2012). Making sense of organizational members' silence: A sensemaking -resource model. Communication Research Reports, 29(3),217-226.

Brinsfield, C. T. (2009). Employee silence: Investigation of dimensionality, development of measures, and examination of related factors. Dissertation. The Ohio State University.

Budak, G., \& Sürgevil, O. (2005). Tükenmişlik ve tükenmişliği etkileyen örgütsel faktörlerin analizine ilişkin akademik personel üzerinde bir uygulama. Dokuz Eylül Üniversitesi i.i.B.F. Dergisi, 20(2), 95-108.

Colquitt, J. A., . Conlon, D.E., Michael, J. W., Porter, C.O.L.H., \& Ng, Y.K. (2001). Justice at the millenium: A meta analytic review of 25 years of organizational justice research. Journal of Applied Pschology, 86(3), 425- 445.

Çakıcı, A. (2007). Örgütlerde sessizlik: Sessizliğin teorik temelleri ve dinamikleri. Ç.Ü. Sosyal Bilimler Enstitüsü Dergisi, $16(1), 145-162$.

Çakıcı, A. (2008). Örgütlerde sessiz kalınan konular, sessizliğin nedenleri ve algılanan sonuçları üzerine bir araştırma. Ç.Ü. Sosyal Bilimler Enstitüsü Dergisi, 17(1), 117-134.

Çakıcı, A. (2010). Örgütlerde işgören sessizliği: Neden sessiz kalmayı tercih ediyoruz? Ankara:Detay Yayıncılık.

Çakır, Ö. (2006). Ücret adaletinin iş davranışları üzerindeki etkileri. Ankara:Kamu İşletmeleri İşverenleri Sendikası.

Çavuş, M.F., Gök, T., \& Kurtay, F. (2007). Tükenmişlik: Meslek Yüksekokulu akademik personeli üzerine bir araştırma. Ç.Ü. Sosyal Bilimler Enstitüsü Dergisi, 16(2), 97-108.

Çetin, Ş., \& Çakmakçı, C. (2012). Çalışan sesliliği ölçeğini türkçeye uyarlama çalışması. KHO Bilim Dergisi, 22(2), 1-19.

Çetinkaya, M., \& Çimenci, S. (2014). Örgütsel adalet algısının örgütsel vatandaşlık davranışı üzerindeki etkisi ve örgütsel özdeşleşmenin aracılık rolü: Yapısal eşitlik modeli çalışması. Yönetim Bilimleri Dergisi, 12(23), 237-278.

Çınar, O., Karcıoğlu, F., \& Alioğulları, Z. D. (2013). The relationship between organizational silence and organizational citizenship behavior: A survey study in the province of Erzurum, Turkey. Procedia-Social and Behavioral Sciences, 99, 314-321

Çiftçi, D., Öztürk, E. M., \& Meriç, A. (2015). Örgütsel sessizlik,tükenmişlik ve işten ayrılma niyeti ilişkisi: Ordu ili özel eğitim ve rehabilitasyon merkezlerinde bir uygulama. Uluslararası Sosyal Araşttrmalar Dergisi, 8(41), 996-1007.

Çöp, S. (2008). Türkiye ve Polonya'da turizm sektörü çalışanlarının örgütsel adalet ve örgütsel bağlılık algılarına ilişkin bir uygulama. Gazi Üniversitesi Eğitim Bilimleri Enstitüsü, Yüksek Lisans Tezi, Ankara.

Deliorman, R. B., Boz, İ. T., Yiğit, ì., \& Yıldız, S. (2009). Tükenmişliği ölçmede alternatif bir araç: Kopenhag Tükenmişlik Envanterinin Marmara Üniversitesi akademik personeli üzerine uyarlaması. İstanbul Üniversitesi Yönetim Dergisi, 20(63), 77-98.

Demirel, Y., \& Dinçer, E. (2011). Örgütsel psikolojisi yeni yaklaşımlar güncel konular. Konya: Atlas Kitabevi.

Dilsiz, B. (2006). Konya ilindeki ortaöğretim okullarında çalışan öğretmenlerin tükenmişlik ve iş doyumu düzeylerinin bölgelere göre değerlendirilmesinin çok değişkenlik istatistiksel analizi. Selçuk Üniversitesi Fen Bilimleri Enstitüsü, Yayınlanmamış Yüksek Lisans Tezi, Konya

Duan, J., Lam, W., Chen, Z., \& Zhong, J. (2010). Leadership justice, negative organizational behaviours, and the mediating effect of affective commitment. Social Bahavior and Personality an international journal, 38(9), 1287-1296.

Eigen, Z. J., \& Litwin, A. S. (2014). Justice or just between us? Empirical evidence of the trade-off between procedural and interactional justice in workplace dispute resolution. ILRReview, 67, 171-201.

Ephratt, M. (2008). The functions of silence. Journal of Pragmatics, 40:1909-1938 
Frenkel, S. J., Min, L., \& Lloyd, D. (2012). Management, organizational justice and emotional exhaustion among chinese migrant workers: Evidence from two manufacturing firms. British Journal of Industrial Relations, 50(1), $121-147$.

Greenberg, J. (1990). Organizational justice: Yesterday, today and tomorrow. Journal of Management, 16(2), $399-432$.

Gül, H., \& Özcan. N. (2011). Mobbing ve örgütsel sessizlik arasındaki ilişkiler: Karaman il özel idaresinde görgül bir çalışma. Kahramanmaraş Sütçü Imam Üniversitesi iiBF Dergisi, 1(2), 107-134.

He, H., Zhu, W., \& Zheng, X. (2014). Procedural justice and employee engagement: Roles of organizational identification and moral identity centrality. J Bus Ethics, 122:681-695.

Hirschman, A. O. (1970). Exit, voice, and loyalty: Responses to decline in firms, organizations, and states. Cambridge, Mass., Harvard University Press. Reprinted by The Social Contract Journal, Summer (1994) Pp.274-275.

Huang, L., \& Huang W. (2016). Interactional justice and employee silence: The roles of procedural justice and affect. Social Behavior and Personality, 44(5), 837-852.

Hur, Won-Moo, Park, S. I., \& Moon, T. W. (2014). The moderating roles of organizational justice on the relationship between emotional exhaustion and organizational loyalty in airline services. Journal of Service Marketing, 28(3), 195-206.

İçerli, L. (2010). Örgütsel adalet: Kuramsal bir yaklaşım. Girişimcilik ve Kalkınma Dergisi, 5(1), 67-92.

İşbaşı, J. Ö. (2001). Çalışanların yöneticilerine duydukları güvenin ve örgütsel adalete ilişkin algılamalarının vatandaşlık davranışının oluşumundaki rolü. Yönetim Araştırmaları Dergisi, 1(1), 51-73.

İşcan, Ö. F., \& Naktiyok, A. (2004). Çalışanların örgütsel bağdaşımlarının belirleyicileri olarak örgütsel bağlılık ve örgütsel adalet algıları. Ankara Üniversitesi Siyasal Bilgiler Fakültesi Dergisi, 59(1), 181-201.

Kahya, C. (2015). Örgütsel sessizlik ve tükenmişlik sendromu ilişkisi. Turkish Studies International Periodical for the Languages, Literature and History of Turkish or Turkic Volume, 10(10), 523-546.

Khalid, J., \& Ahmed, J. (2016). Perceived organizational politics and employee silence: supervisor trust as a moderator. Journal of the Asia Pacific Economy, 21(2), 174-195.

Kılıç, G., Tunç, T., Saraçlı, S., \& Kılıç, í. (2013). Örgütsel stresin örgütsel sessizlik üzerine etkisi: Beş yıldızlı termal otel işletmelerinde bir uygulama. Işletme Araşttrmaları Dergis, 5(1), 17-32.

Kim, H.J., Shin, K.H., \& Swanger, N. (2009). Burnout and engagement: A comparative analysis using the big five personality dimensions. International Journal of Hospitality Management, 28, 96-104.

Köse, G. (2014). Örgütsel adalet algısının tükenmişlik üzerindeki etkisini belirlemeye yönelik bir araşttrma. Hacettepe Üniversitesi Sosyal Bilimler Enstitüsü, Yüksek Lisans Tezi, Ankara.

Kristensen, T.S., Borritz, M., Villadsen E., \& Christensen, K. B. (2005). The Copenhagen Burnout Inventory: A new tool for the assesment of burnout. Work Stress, 19(3), 192-207.

Lambert, E.G., Hogan, N.L., Jiang, S., Elechi, O. O., Benjamin, B., Morris, A., Laux, J.M., \& Dupuy P. (2010). The relationship among distributive and procedural justice and correctional life satisfaction, burnout, and turnover intent: An exploratory study. Journal of Criminal Justice, 38, 7-16.

Laschinger, H.K.S., \& Fida, R. (2014). New nurses burnout and workplace wellbeing: The influence of authentic leadership and psychological capital. Burnout Research, 1, 19-28.

Liljegren, M., \& Ekberg, K. (2009). The associations between perceived distributive, procedural and interactional organizational justice, self-rated health and burnout. IOS Press, Work 33, 43-51.

Loera B., Gattino S., \& Converso, D. (2013). Giustizia organizzativa, supporto sociale e burnout tra lavoratori della Sanità: effetti diretti e di moderazione, Psicologia della Salute, 1, 27-48.

Makens, M.A., (2016). Employee voice: The roles of organizational identification, informational justice and power distance. Dissertation, Catolica Lisbon.

Meydan, C.H., Şeşen H., Basım, N. (2011). Adalet algısı ve tükenmişliğin örgütsel vatandaşlık davranışları üzerindeki öncüllük rolü. "iş, GÜÇ" Endüstri Ilişkileri ve Insan Kaynakları Dergisi, 13(2), 41-62.

Morrison, E.W. (2014). Employee voice and silence. Annual Review of Organizational Psychology and Organizational Behavior, 1, 173-197.

Morrison, E.W., \& Milliken, F.J. (2000). Organizational silence: A barrier to change and development in a pluralistic world. Academy of Management Review, 25(4), 706-725.

Özçınar, M.F., Demirel, Y., \& Özbezek B.D. (2015). Çalışanların örgütsel adalet algıları ve örgütsel sessizlik arasındaki ilişkinin incelenmesi. Mehmet Akif Ersoy Üniversitesi SBE Dergisi, 7(13), 150-171.

Özdemir, A. (2016). Yönetim biliminde ileri araştırma yöntemleri ve uygulamalar. 4. Baskı, Beta Yayıncılık. 
Özdemir, L., \& Uğur, S.S. (2013). Çalışanların örgütsel ses ve sessizlik algılamalarının demografik nitelikler açısından değerlendirilmesi: Kamu ve özel sektörde bir araştrrma. Atatürk Üniversitesi i.i.B.F. Dergisi, 27(1), 257-281.

Özer, P.S., \& Urtekin, G.E. (2007). Örgütsel adalet algısı boyutları ve iş doyumu ilişkisi üzerine bir araştırma. Erciyes Üniversitesi iiBF Dergisi, 28, 107-125.

Özgan, H., \& Külekçi, E. (2012). Öğretim elemanlarının sessizlik nedenleri ve üniversitelerine etkileri. E-International Journal of Educational Research, 3(4), 33-49.

Özmen, Ö.T., Arbak Y., \& Özer, P.S. (2007). Adalete verilen değerin adalet algıları üzerindeki etkisinin sorgulanmasına ilişkin bir araştırma. Ege Akademik Bakış, 7(1), 17-33.

Pelit, E., \& Bozdoğan, ì. (2014). Çalışanların örgütsel adalet algılamalarının tükenmişlik düzeyleri üzerindeki etkisi: Kemer'deki beş yıldızlı otel işletmelerinde bir uygulama. İ̧̧letme Araştırmaları Dergisi, 6(2), 37-66.

Pinder, C.C., \& Harlos, K.P. (2001). Employee silence: Quiescence and acquiescence as responses to perceived injustice. Research in Personnel and Human Resources Management, 20, 331-369.

Sevim, L. (2011). Tükenmişlik ve ise bağlılığın örgütsel vatandaşlık davranışı üzerindeki etkisi: Turizm sektöründe bir araştirma. Hacettepe Üniversitesi Sosyal Bilimler Enstitüsü, Doktora Tezi, Ankara.

Shibaoka, M., Takada M., Watanabe M., Kojıma R., Kakınuma M., Tanaka, K., \& Kawakami, N. (2010). Development and validity of the Japanese version of the organizational justice scale. Industrial Health, 48, 66-73.

Son, S., Kim, D., \& Kim, M. (2014). How perceived interpersonal justice relates to job burnout and intention to leave: The role of leader-member exchange and cognition-based trust in leaders. Asian Journal of Social Psychology, 17, 12-24.

Sökmen, A., Bilsel, M.A., \& Erbil, C. (2013). Örgütsel adaletin çalışan motivasyonu ve performası üzerindeki etkisi: Bankacılık sektöründe bir araştırma. Gazi Üniversitesi iiBF Dergisi, 15(1), 1-20.

Şeşen, H. (2011). Adalet algısının tükenmişliğe etkisi: İş tatmininin aracı değişken rolünün yapısal eşitlik modeli ile testi. ww.kho.edu.tr/akademik/enstitu/savben_dergi/92/Makale4.pdf. Erişim:19.06.2016.

Tahmasebi, F., Sobhanipour, S.M., \& Aghaziarati, M. (2013). Burnout; explaining the role of organizational silence and its influence (Case study: selected executive organizations of qom province). Journal of Basic and Applied Scientific Research, 3(8), 272-282.

Tangirala, S., \& Ramanujam, R. 2008. Employee silence on critical work issues: The cross level effects of procedural justice climate. Personnel Psychology, 61, 37-68.

Tikici, M., Derin N., \& Kalkın, G. (2011). Örgütsel sessizliğin duygusal tükenmişliğe etkisi. 7. KOBi'ler ve Verimlilik Kongresi Bildiri Kitabı, 253-261.

Torun, G.S. (2015). Örgütsel adalet ve sessizlik ilişkisi. Kalkınmada Anahtar Verimlilik Dergisi, Sayı: 322. https://anahtar.sanayi.gov.tr/tr/news/orgutsel-adalet-ve-sessizlik-iliskisi/2143, Erişim: 04 Aralık 2016.

Tulubaş, T., \& Celep C. (2012). Effect of perceived procedural justice on faculty members' silence: The mediating role of trust in superior. Social and Behavioral Sciences, 47, 122-123.

Türk Dil Kurumu, 2005. 1741; www.tdk.gov.tr Erişim: 24 Ekim 2016.

Uluköy, M. (2014). Sağlık çalışanlarının örgütsel adalet algısı ile tükenmişlik duyguları arasındaki ilişki: Bir uygulama. Dumlupınar Üniversitesi Sosyal BilimlerDergisi, 39, 213-226.

Üngüren, E., Doğan H., Özmen M., \& Tekin, Ö.A. (2010). Otel çalışanlarının tükenmişlik ve iş tatmin düzeyleri ilişkisi. Journal of Yasar University, 17(5), 2922-2937.

Ünlü, Y., Hamedoğlu, M.A., \& Yaman, E. (2015). The relationship between perceived organizational justice and organizational silence level of teachers. Sakarya University Journal of Education, 5(2), 140-157.

Van Dyne, L., Ang S., \& Botero, I.C. (2003). Conceptualizing employee silence and employee voice as multidimensional constructs. Journal of Management Studies, 40(6), 1359-1392.

Wang, R., \& Jiang J. (2015). How abusive supervisors influence employees' voice and silence: The effects of interactional justice and organizational attribution. The Journal of Social Psychology, 155, 204-220.

Whiteside, D.B., \& Barclay, L.J. (2013). Echoes of silence: Employee silence as a mediator between overall justice and employee outcomes. J Bus Ethics, 116, 251-266.

Xu, A., Loi, R., \& Lam, L. W. (2015). The bad boss takes it all: How abusive supervision and leader-member exchange interact to influence employee silence. The Leadership Quarterly, 26(5), 763-774.

Yaman, E., \& Ruçlar, K. (2014). Örgüt kültürünün yordayıcısı olarak üniversitelerde örgütsel sessizlik. Yükseköğretim ve Bilim Dergisi, 4(1), 36-50. 
Yeniçeri, Ö., Demirel, Y., \& Seçkin, Z. (2009). Örgütsel adalet ile duygusal tükenmişlik arasındaki ilişki: imalat sanayi çalışanları üzerine bir araştırma. KMU iiBF Dergisi, 11(16):, 83-99.

Yıldırım, M.C., Ekinci, A., \& Öter, Ö.M. (2012). Eğitim müfettiş yardımcılarının örgütsel adalet algılarının mesleki tükenmişlik düzeylerine etkisi. Ankara Üniversitesi Eğitim Bilimleri Fakültesi Dergisi, 45(1), 327-345.

Yıldız, S., Yalavaç, S., \& Meydan, C.H. (2013). Tükenmişliğin işten ayrılma niyetine etkisinde örgüte bağlılığın aracı rolü: Türkiye'deki gümrük ve ticaret bakanlığı personeli üzerinde bir araştırma. Bilgi Ekonomisi ve Yönetimi Dergisi, $8(2), 157-170$.

Zahed, R. K. (2015). The mediating effect of social undermining on the relationship between organizational justice and organizational silence. European Online Journal of Natural and Social Sciences, 4(4), 752-760.

Zhang, X., Zhou L., Zhao S. (2013). An emprical study on the relationship between organizational justice profile and employee silence. Chinese Journal of Management, 5, www.cnki.com.cn Erişim Tarihi: 14.03.2017. 